Article

\title{
Gemstones of Greece: Geology and Crystallizing Environments
}

\author{
Panagiotis Voudouris ${ }^{1, *}{ }^{\oplus}$, Constantinos Mavrogonatos ${ }^{1}\left(\mathbb{D}\right.$, Ian Graham ${ }^{2}\left(\mathbb{D}\right.$, Gaston Giuliani $^{3}$, \\ Alexandre Tarantola ${ }^{4}\left(\mathbb{D}\right.$, Vasilios Melfos ${ }^{5}\left(\mathbb{D}\right.$, Stefanos Karampelas ${ }^{6} \mathbb{D}$, \\ Athanasios Katerinopoulos ${ }^{1}$ and Andreas Magganas ${ }^{1}$ (D) \\ 1 Faculty of Geology and Geoenvironment, National and Kapodistrian University of Athens, \\ GR-15784 Athens, Greece \\ 2 PANGEA Research Centre, School of Biological, Earth and Environmental Sciences, University of NSW, \\ 2052 Sydney, Australia \\ 3 CRPG/CNRS, Université Paul Sabatier, GET/IRD et Université de Lorraine, 54501 Vandœuvre cedex, France \\ 4 GeoRessources, Faculté des Sciences et Technologies, Université de Lorraine, CNRS, \\ F-54506 Vandœuvre-lès-Nancy, France \\ 5 Faculty of Geology, Aristotle University of Thessaloniki, 54124 Thessaloniki, Greece \\ 6 Bahrain Institute for Pearls \& Gemstones (DANAT), WTC East Tower, P.O. Box 17236 Manama, Bahrain \\ * Correspondence: voudouris@geol.uoa.gr; Tel.: +30-210-727-4129
}

Received: 28 June 2019; Accepted: 26 July 2019; Published: 29 July 2019

\begin{abstract}
In the Hellenides Orogen, minerals of various gem quality occur in various rock types from mainly four tectono-metamorphic units, the Rhodope, Pelagonian, and the Attico-Cycladic massifs, and the Phyllites-Quartzites unit of Crete Island. In crystalline rocks, gemstones are related to both regional metamorphic-metasomatic processes (e.g., gem corundums, Mn-andalusite, thulite/clinothulite, spessartine, titanite, jadeite), and to the formation of late alpine-type fissures, such as, for example, quartz, albite, adularia and titanite. The Tertiary (and Mesozoic) magmatic-hydrothermal environments provide gem-quality sapphire, beryl, garnet, vesuvianite, epidote, fluorite, and $\mathrm{SiO}_{2}$ varieties. The supergene oxidation zone of the Lavrion deposit hosts gem-quality smithsonite and azurite. Coloration in the studied material is either due to various chromophore trace elements present in the crystal structure, or due to inclusions of other mineral phases. Future modern exploration methods combined with gemological investigations (such as treatment and faceting of selected stones), are necessary in order to obtain a better knowledge of the gemstone potential of Greece for its possible exploitation.
\end{abstract}

Keywords: gemstones; corundum; beryl; jadeitite; garnet; quartz varieties; Greece

\section{Introduction}

By definition, gems are materials used for adornment or decoration that must be relatively rare, hard, and tough enough (shock resistant) to resist "normal" wear and withstand corrosion by skin contact and cosmetics [1]. Gems have been prized for thousands of years for their color, luster, transparency, durability, and high value-to-volume ratio [1,2]. A natural gem is one that has been fashioned (or faceted) after having been found in nature, even if it later undergoes treatment processes. Gem materials cover a large variety of products found in the jewelry market today. Most natural gems are single crystals of natural minerals, although others are amorphous (some varieties of opal, natural glass), some are solid solutions (garnets, peridot, etc.), others are rocks (jade, lapis), and some are composed partly or wholly of organic materials (amber, pearl, coral, etc.) [1].

According to Groat [3,4] and Stern et al. [5], any mineral or stone beautiful enough to be sought, mined, and sold for its beauty alone is a gemstone. Among the most important gemstones are diamond, 
ruby (red-colored corundum) and sapphire (blue-colored corundum), emerald and other gem forms of the mineral beryl, chrysoberyl, tanzanite (blue zoisite), tsavorite (green grossular garnet), "paraiba-type" tourmaline (copper-colored "neon"-blue tourmaline), topaz and jadeite-"jade" (jadeitite) [4]. More common gem materials include, among others, amber, silica gems, feldspar, tourmaline, spinel, garnets, zircon etc. It is not the mineral itself that makes a gemstone, it is the characteristics of a specific sample [2].

Understanding the geological conditions that give rise to gem deposits is of great importance because it can provide guidelines for exploration $[2,3,6]$. Specific geological conditions include the availability of uncommon major constituents, the presence of adequate chromophores and open space in order to form crystals of sufficient size and transparency [2], and the absence of dramatic post-growth events (e.g., fracturing).

Traditionally, Greece has not been regarded as a source country for gemstones [7]. Known gem material included rubies from Xanthi [8], sapphire and beryl from Naxos Island [9], red-colored spessartine from Paros Island [10], smithsonite from the oxidation zone of the Lavrion mines [11], and the green quartz variety (prase) from the Serifos skarn [12]. Exploration work in Greece over the last three decades has resulted in the discovery of new occurrences of mineral megacrysts many of them being gem-quality [13-19]. The gemstones of Greece are set within diverse geological settings, the study of which will increase our knowledge on the conditions necessary for their crystallization and concentration into economically-viable deposits. The aim of this work is to review all available information on the geology, mineralogy, geochemistry, and fluid characteristics involved in the formation of various gemstones in Greece. The occurrences of gemstones in Greece are presented in Figures 1 and 2 and described with respect to their geological framework and the conditions of their formation.

\section{Materials and Methods}

Analytical methods included optical and electron microscopy, X-ray powder diffraction studies, and electron microprobe analyses, in the Section of Mineralogy-Petrology at University of Athens and at the Institute of Mineralogy and Petrology, University of Hamburg. X-ray powder diffraction measurements were obtained using a SIEMENS D-500 diffractometer with $\mathrm{Cu}$ tube and $\mathrm{Co}$ filter. For the mineral analyses, a scanning electron microscope JEOL JSM-5600 combined with an energy dispersive $X$-ray microanalysis system Oxford Link Isis 300 system were used. Thin and thin-and-polished sections of mineral samples and host rocks were studied by a JEOL JSM 5600 scanning electron microscope equipped with back-scattered imaging capabilities, respectively, at the Department of Mineralogy and Petrology at the University of Athens (Greece). Quantitative analyses were carried-out at the Institute of Mineralogy and Petrology, University of Hamburg using a Cameca-SX 100 WDS. Analytical conditions were as follows: accelerating voltage of $20 \mathrm{kV}$, a beam current of $20 \mathrm{nA}$ and counting time of $20 \mathrm{~s}$ for $\mathrm{Al}, \mathrm{Si}, \mathrm{Ca}, \mathrm{Fe}$ and $\mathrm{Mg}, 60 \mathrm{~s}$ for $\mathrm{Mn}$ and $120 \mathrm{~s}$ for $\mathrm{Cr}$. The $\mathrm{X}$-ray lines used were: $\mathrm{AlK} \alpha, \mathrm{SiK} \alpha$, $\mathrm{TiK} \alpha, \mathrm{FeK} \alpha, \mathrm{MnK} \alpha, \mathrm{MgK} \alpha, \mathrm{CrK} \alpha$, and $\mathrm{CaL} \alpha$. The standards used were: andradite (for $\mathrm{Si}, \mathrm{Ca}$ and $\mathrm{Fe}$ ), and synthetic $\mathrm{Al}_{2} \mathrm{O}_{3}$ (for $\mathrm{Al}$ ), $\mathrm{MnTiO} 3$ (for $\mathrm{Mn}$ and $\mathrm{Ti}$ ), $\mathrm{Fe}_{2} \mathrm{O}_{3}$ (for $\mathrm{Fe}$ ), $\mathrm{Cr}_{2} \mathrm{O}_{3}$ (for $\mathrm{Cr}$ ), and $\mathrm{MgO}$ (for $\mathrm{Mg}$ ). Corrections were applied using the PAP online program [20].

LA-ICP-MS analyses presented in this study are from Voudouris et al. [18]. The analyses were conducted at the CODES ARC Centre of Excellence in Ore Deposits of the University of Tasmania, Australia, and the Institute of Mineralogy, University of Münster, Germany. For analytical conditions see Voudouris et al. [18].

Stable isotope analyses were performed at the Stable Isotope and Atmospheric Laboratories, Department of Geology, Royal Holloway, University of London (London, UK). The oxygen isotope composition of quartz was obtained using a $\mathrm{CO}_{2}$ laser fluorination system similar to that described by Mattey [21]. Each mineral, separate or standard, is weighed at $1.7 \mathrm{mg} \pm 10 \%$. These were loaded into the 16-holes of a nickel sample tray, which was inserted into the reaction chamber and then evacuated. The oxygen was released by a $30 \mathrm{~W}$ Synrad $\mathrm{CO}_{2}$ laser in the presence of $\mathrm{BrF}_{5}$ reagent. The yield of 
oxygen was measured as a calibrated pressure based on the estimated or known oxygen content of the mineral being analyzed. Low yields result in low $\delta^{18} \mathrm{O}$ values for all mineral phases, so accurate yield calculations are essential. Yields of $>90 \%$ are required for most minerals to give satisfactory $\delta^{18} \mathrm{O}$ values. The oxygen gas was measured using a VG Isotech (now GV Instruments) Optima dual inlet isotope ratio mass spectrometer (IRMS). All values are reported relative to Vienna Standard Mean Ocean Water (V-SMOW). The data are calibrated to a quartz standard (Q BLC) with a known $\delta^{18} \mathrm{O}$ value of $+8.8 \%$ V-SMOW from previous measurements at the University of Paris-6 (France). This has been further calibrated for the RHUL laser line by comparison with NBS-28 quartz. Each 16-hole tray contained up to 12 sample unknowns and 4 of the Q BLC standard. For each quartz run a small constant daily correction, normally less than $0.3 \%$, was applied to the data based on the average value for the standard. Overall, the precision of the RHUL system based on standard and sample replicates is better than $\pm 0.1 \%$.

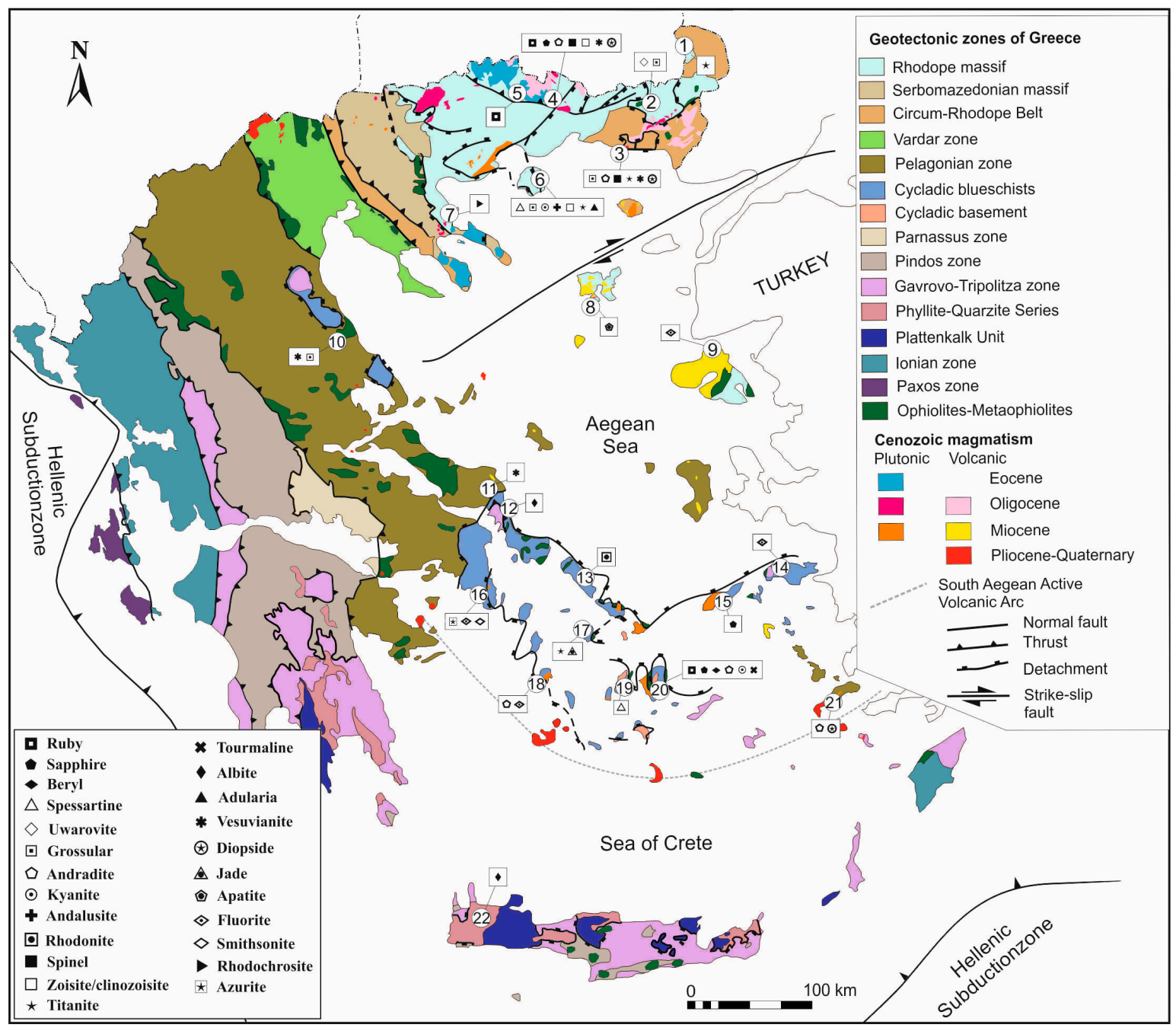

Figure 1. Occurrences of various gemstones in metamorphic and igneous rocks of Greece (Geological map of Greece modified after Ottens and Voudouris [17]): 1. Therapio/Evros, 2. Vyrsini/Evros, 3. Maronia/Rhodopi 4. Gorgona-Kimmeria/Xanthi, 5. Paranesti/Drama, 6. Trikorfo/Thassos, 7. Stratoni-Olympiada/Chalkidiki, 8. Fakos/Limnos Island, 9. Megala Therma/Lesvos Island, 10. Larissa, 11. Kymi/Evia Island, 12. Krieza-Koskina/Evia Island, 13. Petalo/Andros Island, 14. Ampelos/Samos Island, 15. Pounta/Ikaria Island, 16. Lavrion/Attica, 17. Kampos/Syros Island, 18. Agia Marina-Avessalos/Serifos Island, 19, Thapsana/Paros Island, 20. Kinidaros-Kavalaris/Naxos Island, 21. Kardamena/Kos Island, 22. Lakkoi/Crete Island. 


\section{Geological Setting}

The Hellenides constitute part of the Alpine-Himalayan Orogen and formed when Apulia collided with Europe during the Late Cretaceous to Tertiary. They are subdivided into several units: the Rhodope Massif, Servo-Macedonian Massif, Vardar Zone, Pelagonian Zone (Internal Hellenides) and the External Hellenides built-up by Mesozoic and Cenozoic rocks [22-25] (Figures 1 and 2). The Hellenides can be considered an accretionary orogen, resulted from thrusting and SW-verging nappe-stacking of the Rhodopes, Pelagonia and Adria continental blocks, and closure of the Vardar and Pindos oceanic domains of the Neotethys [22]. A Permo-Carboniferous igneous event (known from the Pelagonian Zone, the Rhodope Massif, the Attico-Cycladic Zone, Peloponnese and Crete) documents an active continental margin evolution in the Precambrian-Silurian basement of the Hellenides. Final collision between Europe and Pelagonia at the end of the Cretaceous closed the Neotethys Ocean along the Vardar Suture Zone, as evidenced by obducted Jurassic ophiolites on the Pelagonia continental block [26].

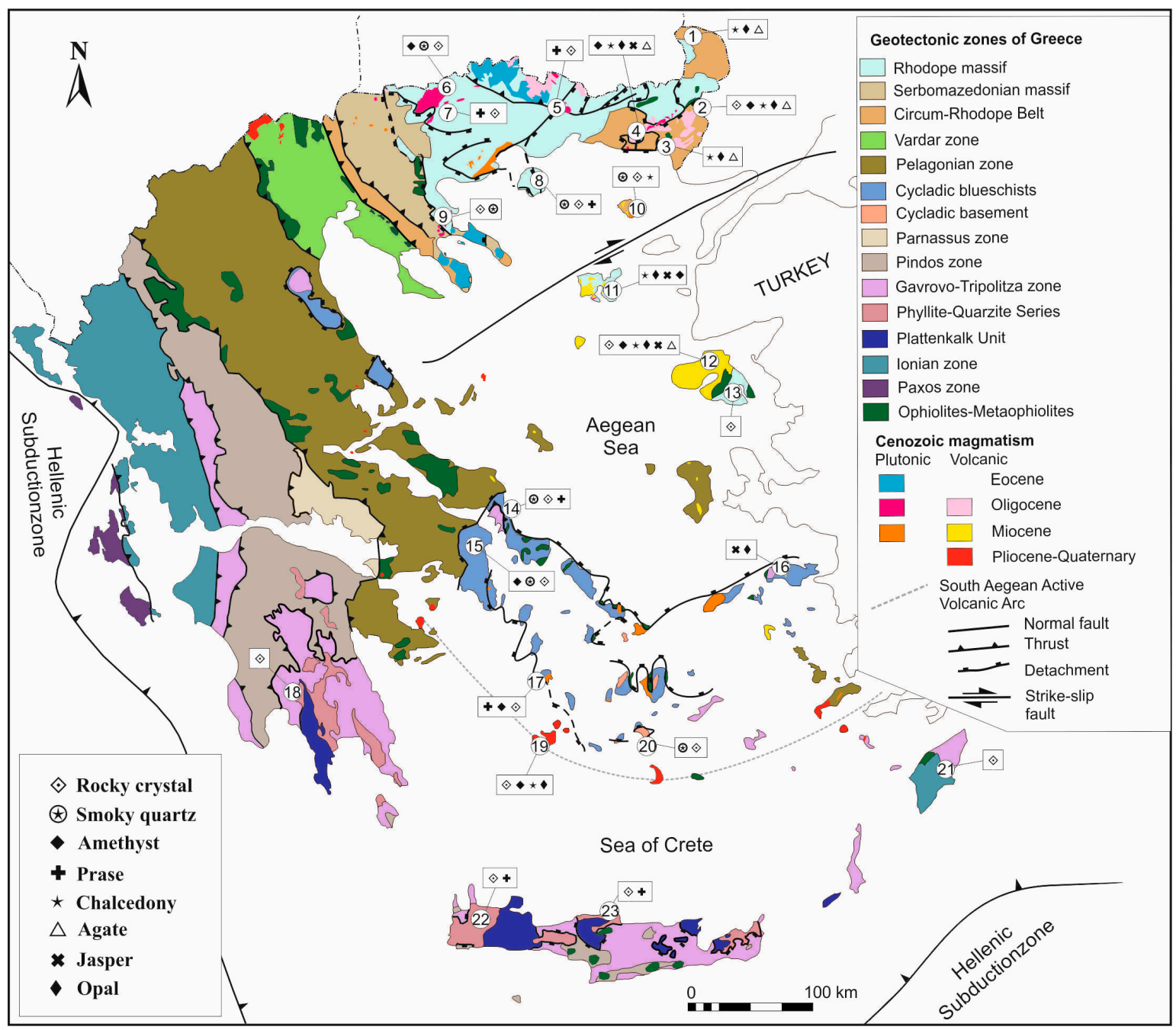

Figure 2. Occurrences of gem-quality silica varieties in metamorphic and igneous rocks of Greece (Geological map of Greece modified after Ottens and Voudouris [17]): 1. Dikea/Evros, 2. Kornofolia/Evros, 3. Aetochori/Evros 4. Sapes/Rhodopi, 5. Kimmeria/Xanthi, 6. Dassoto/Drama, 7. Cresti/Drama, 8. Trikorfo/Thassos, 9. Stratoni-Olympiada/Chalkidiki, 10. Fengari/Samothraki, 11. Moudros-Roussopouli/Limnos Island, 12. Megala Therma/Lesvos Island, 13. Geras/Lesvos, 14. Krieza-Koskina/Evia Island, 15. Penteli Mt/Attika, 16. Ampelos/Samos Island, 17. Avessalos/Serifos Island, 18 Taygetos,. 19. Chondro Vouno-Vani/Milos Island, 20. Mylopotas/Ios Island, 21. Rhodes Island, 22. Prases/Crete Island, 23. Agia Pelagia/Crete Island. 
Shortening and syn-orogenic exhumation of HP-LT rocks occurred during the late Cretaceous-Eocene, before an acceleration of slab retreat changed the subduction regime and caused the collapse of the Hellenic mountain belt and thinning of the Aegean Sea from the middle Eocene/late Oligocene to the present [22]. During this post-orogenic episode, large-scale detachments formed, which exhumed metamorphic core complexes in a back-arc setting. Tertiary magmatism in the Aegean region occurred mostly in a post-collisional setting behind the active Hellenic subduction zone [26]. The Pliocene to recent volcanic rocks in the active Aegean volcanic arc formed as a consequence of active subduction beneath the Hellenic trench. In the Hellenides Orogen, gemstones occur in various rock types of mainly three tectono-metamorphic units, the Rhodope- and the Attico-Cycladic massifs and the Phyllites-Quartzites unit of Crete Island.

\section{Formation Environments of Gems: An Overview}

\subsection{Metamorphic-Metasomatic}

In crystalline rocks, two groups of gemstones are distinguished: those formed during regional metamorphism-metasomatism and those associated with late alpine-type fissures [14-16,18,19,27-29] (Figures 1 and 2). The first group includes ruby, sapphire, jadeite "jade" (jadeitite), Mn-andalusite, spessartine, Mn-grossular, Mn-zoisite/clinozoisite, Fe-Mn-bearing kyanite and rhodonite. Corundums in the Xanthi-Drama areas (Rhodope massif) and Naxos-Ikaria Islands (Attico-Cycladic massif), are hosted in pargasitic schists, marbles and metabauxites. Host rocks are Carboniferous orthogneisses, metapelites and skarns for Mn-andalusite, spessartine and thulite at Thassos Island, Permian - Middle Triassic schists for rhodonite in Andros Island (Attico-Cycladic massif, [30]) and orthogneisses and marbles in Paros Island [10]. Jadeitites, eclogites and blueschists are host rocks for jadeite "jade" and titanite at Syros Island.

Alpine-type fissure minerals [31,32] in Greece are related to tension gashes formed under brittle-ductile to ductile conditions during the retrograde, late-stage exhumation of metamorphic core complexes $[14,33,34]$. The alpine-type fissures in Greece contain gem-quality quartz and albite together with adularia, chlorite, epidote, actinolite, hematite, muscovite, rutile, tourmaline and pyrite. Host lithologies are ortho- and paragneisses in the Rhodope Massif (Drama, Thassos Island) and Attico-Cycladic Massif (Penteli Mt, Evia, Ios Islands), amphibolites (Evros, Thassos, Evia and Andros Islands) and finally phyllites (Lesvos Island) and metaquartzites (Crete Island). Quartz in both transparent smoky and colorless (rock crystal) varieties were found in all the above localities and/or host rocks-deep violet amethyst occurs in orthogneisses at Drama area [34]. Albite crystals of gem-quality are abundant in metabasites from Crete Island and orthogneisses from Evia Island.

\subsection{Magmatic-Hydrothermal}

The Tertiary (and Mesozoic) magmatic-hydrothermal environments in Greece (granitoids, pegmatites, skarns, non-skarn carbonate-replacement deposits, volcanic and ophiolitic rocks) also provide gem-quality material of beryl, corundum, garnet, vesuvianite, diopside, epidote, titanite, spinel, fluorite, rhodochrosite, quartz varieties, and silica microcrystalline species (Figures 1 and 2). Miarolitic cavities and quartz veins cross-cutting granitoids host gem-quality quartz varieties and apatite. Samothraki and Limnos Islands in the northern Aegean, and Kimmeria/Xanthi, Maronia/Rhodopi in the mainland of northern Greece and Tinos Island in the Cyclades are the most important localities. The Greek pegmatites are mostly deficient in miarolitic cavities, and thus contain only matrix embedded mineral crystals. On Naxos Island, blue sapphires are associated with granite pegmatites intruding ultramafic lithologies (plumasites). Blue beryl crystals (var. aquamarine) are typical constituents of Naxos pegmatites both within the migmatitic domes as well as in pegmatites cross-cutting the surrounding metamorphic rocks. Black tourmaline crystals occur in pegmatites near Nevrokopi-Drama and at Naxos Island. 
The skarns of Serifos, Kimmeria/Xanthi and Drama, are characterized by abundant quartz. Epidote crystals are associated with quartz at Lefkopetra, near Kimmeria within metasomatized granodiorite and gneiss-hosted exoskarn bodies. Vesuvianite occurs at Kimmeria and Maronia exoscarns, and garnet is a major constituent of the Greek skarns and represented by several gemmy varieties at Maronia, Kimmeria, Kresti, Kos and Serifos. Titanite and spinel occur in the Maronia endo- and exoskarns respectively. The carbonate-replacement $\mathrm{Pb}-\mathrm{Zn}-\mathrm{Au}-\mathrm{Ag}$ deposits of Stratoni, Olympias, Lavrion and Serifos host a large variety of non-metallic minerals of gem-quality of both hypogene and supergene origin. Primary, gem-quality minerals from the Chalkidiki mines include: quartz and rhodochrosite. The Lavrion and Serifos deposits are well-known localities for fluorite. Rodingitized gabbros and dolerites at Evros, Evia, Larissa and Othrys Mesozoic ophiolites (Rhodope massif and Pelagonian zone) host gem-quality hessonite and vesuvianite [17].

Hydrothermal-altered volcanic rocks throughout Greece host several silica varieties most of them in gem-quality. Amethyst and chalcedony occur at Kornofolia/Evros area, in Sapes-Rhodopi region and in Lesvos and Milos Islands in epithermal veins accompanying calcite, and/or adularia and barite [35]. Opal occurs in several varieties and colors at Lesvos and Limnos Islands being a constituent of fossilized wood, as well as at various localities at Evros and Milos, Limnos and Lesvos Island and is considered to be part of either silica sinters or steam-heated alteration zones. Fluorite megacrysts occur at Samos and Lesvos Islands, in both cases in the form of monominerallic fluorite veins, cross-cutting epithermally-altered silicified zones and propylitically altered lavas, respectively.

\section{Mineralogy of Gems}

\subsection{Corundum}

Greece contains gem corundums mostly within the Rhodope (Xanthi and Drama areas) and Attico-Cycladic (Naxos and Ikaria Islands) tectono-metamorphic units (Figures 1 and 3). In the Xanthi area (Gorgona-Stirigma localities) sapphire deposits are stratiform, occurring within marble layers alternating with eclogitic amphibolites [18,36,37] (Figure 3a). Rubies in the Paranesti-Drama area are restricted to boudinaged lenses of pargasitic schists alternating with amphibolites and gneisses [28,29]. Both occurrences are oriented parallel to the UHP-HP Nestos suture zone. Sapphire from Xanthi marbles is of pink, orange, purple to blue color, usually of tabular or barrel-shaped euhedral form and reaches sizes of up to $4 \mathrm{~cm}$ (Figure $3 \mathrm{~b}, \mathrm{c}$ ). In some cases, blue corundum alters to spinel. The corundums from Xanthi are transparent with very clear parting and fine cracks. Blue sapphires are zoned, with alternating deep blue and colorless domains. This zoning, or irregular color distribution in the sapphires, is attributed to different Fe and Ti contents in the crystals [18]. The Xanthi sapphires are associated with calcite, dolomite, brown or blue spinel, margarite, and nickeloan tourmaline.

In the Paranesti/Drama area, rubies are associated with kyanite and pargasitic hornblende, and are rimmed by margarite, muscovite, chlorite and chromian spinel. Ruby crystals, ranging in size up to $5 \mathrm{~cm}$ and of pale pink to deep red color [28], are mainly flat tabular and less commonly prismatic and barrel-shaped (Figure 3d). The Paranesti rubies are opaque to transparent exhibiting clear parting and lamellar twinning.

On Naxos Island, about $2 \mathrm{~km}$ East and Southeast of Kinidaros, blue sapphires up to $3 \mathrm{~cm}$ are associated with granite pegmatites intruding ultramafic lithologies (plumasites), occurring either within the pegmatites themselves or the surrounding metasomatic reaction zones $[18,37,38]$ (Figure 3e). Within the plumasites, colorless to blue, purple, and pink corundum may occur either as isolated crystals within the plagioclase matrix, and/or associated with tourmaline and phlogopite (Figure 3f). In the blackwalls that developed at the contacts between the pegmatites and the meta-peridotite country rock purple and pink sapphires are enveloped by phlogopite. The Naxos plumasite sapphire crystals are barrel-shaped, display macroscopic color zoning from a blue core surrounded by a white rim or as a blue-zoned outer rim surrounding a colorless core, or pink cores to purple rims [18]. They are transparent with inner fractures. In the southern part of the Island, close to Kavalaris Hill, a rock 
termed "corundite" by Feenstra and Wunder [39], which was formed by the dissociation of former diasporites, in meta-bauxites during prograde regional metamorphism, is composed almost entirely of blue corundum. The corundum from this locality does not occur in well-shaped crystals, it is mostly massive, and translucent to opaque, appropriate only to be cut as cabochon.
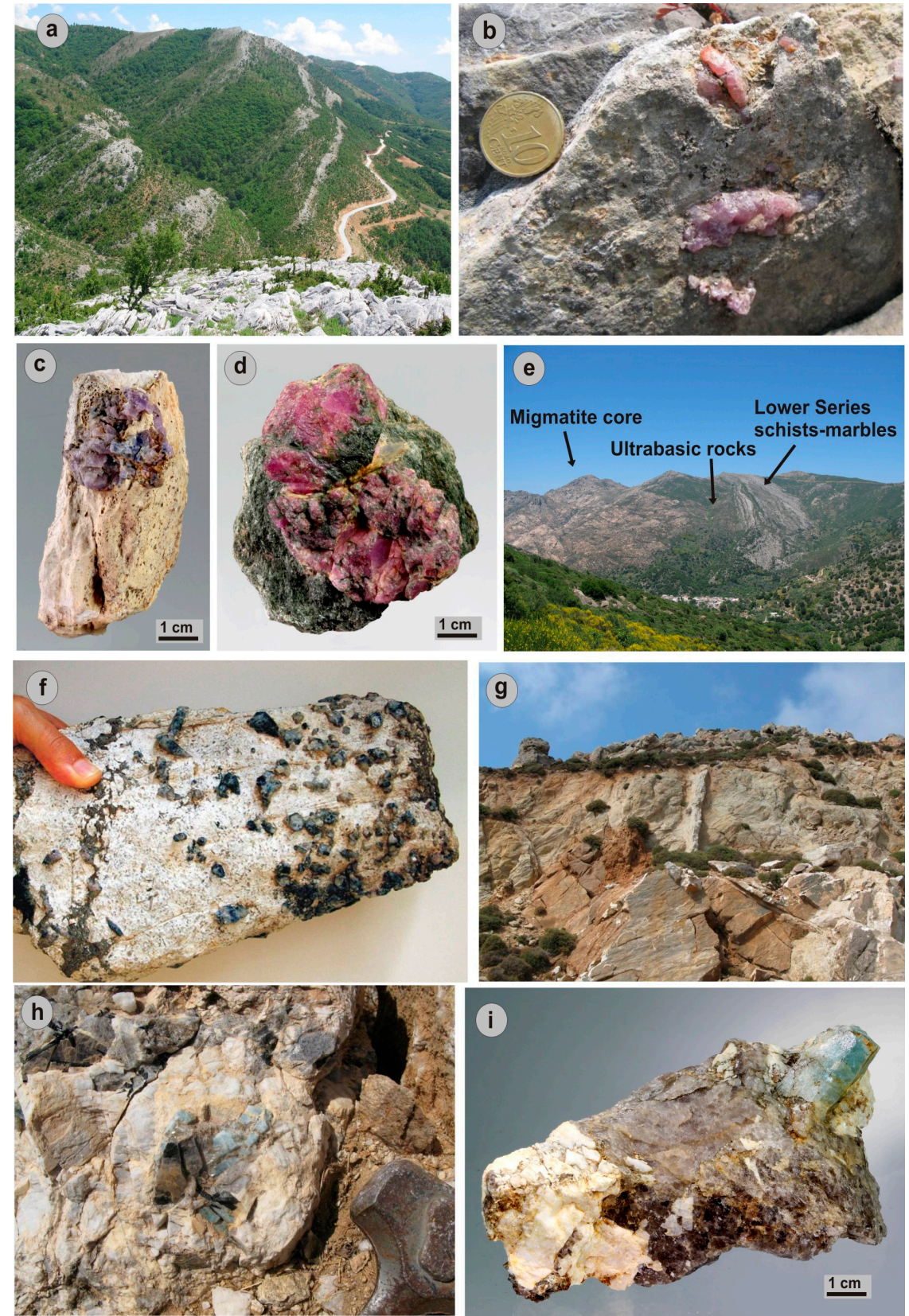

Figure 3. Field and hand specimens photographs demonstrating gem corundum and beryl occurrences/crystals from Greece: (a) Corundum-bearing marbles alternating with amphibolites along the Nestos suture zone, Gorgona/Xanthi area; $(\mathbf{b}, \mathbf{c})$ Pink to purple sapphires within Xanthi marbles; (d) Ruby within pargasite schist from Paranesti/Drama; (e) Ultrabasic bodies rimming the migmatite core of Naxos Island. Plumasite formation took place after metasomatic reaction between ultrabasites and pegmatites, (f) Blue and colorless sapphires within desilicated pegmatite (plumasite) from Kinidaros, Naxos Island; (g) Beryl-bearing pegmatite penetrating migmatite at Kinidaros, Naxos Island, (h,i) Blue beryl (var. aquamarine) associated with orthoclase and muscovite within pegmatite from Kinidaros, Naxos Island. Photographs 3c,d,i are courtesy of Berthold Ottens. 
On Ikaria Island, blue sapphires occur in the metabauxites of Atheras Mt, hosted within marbles, which lie on top of gneisses. The corundum megacrysts fill together with margarite, extensional fissures and networks of veins discordant to the metabauxite foliation [18,37]. The corundums are deep-blue in color, tabular to well-shaped, reach sizes up to $4 \mathrm{~cm}$ and are accompanied by Fe-chlorite, hematite, rutile and diaspore. The corundum contains inclusions of ilmenite, hematite, ulvospinel, rutile and zircon.

The LA-ICP-MS results for averages and ranges for chromophores and genetic indicator elements (Fe, Cr, Ti, V, Ga and Mg) are listed in Table 1. Colorless to blue sapphires from Gorgona/Xanthi display significant variations in their Ti content which reflects their zoned coloration. Bluish areas display high Ti values up to $6462 \mathrm{ppm}$, and pink varieties are characterized by much less Ti (up to 810 ppm). Iron content reaches values up to $1339 \mathrm{ppm}$ in both colorless and blue areas and up to $1782 \mathrm{ppm}$ in the pink varieties. Pink corundums are characterized by significantly higher $\mathrm{Cr}$ (up to $1082 \mathrm{ppm}$ ) concentrations, compared to the colorless/blue areas ( $\mathrm{Cr}<298 \mathrm{ppm})$. Maximum values for $\mathrm{V}$ and $\mathrm{Ga}$ content of up to 227 and $121 \mathrm{ppm}$, respectively are fixed regardless of the color. $\mathrm{Mg}$ values (up to $536 \mathrm{ppm}$ ) are generally higher in the colorless to blue grains, compared to the pink grains ( $<65 \mathrm{ppm})$. Rubies from Paranesti/Drama display very high Cr contents (up to 15347 ppm), and Fe (up to 4348 ppm). The Ti, $\mathrm{Mg}$, Ga and V values are low (up to 148, 31, 24 and 6 ppm, respectively).

Table 1. Chromophores and key trace elements (Mg and Fe) LA-ICP-MS analyses (ppm) of the Greek corundum crystals (data from Voudouris et al. [18]).

\begin{tabular}{|c|c|c|c|c|c|c|c|c|c|}
\hline $\begin{array}{c}\text { Sample } \\
\text { (Number of } \\
\text { Analyses) }\end{array}$ & Locality & Color & ppm & $\mathrm{Mg}$ & $\mathrm{Ti}$ & V & $\mathrm{Cr}$ & $\mathrm{Fe}$ & $\mathrm{Ga}$ \\
\hline \multirow{3}{*}{ Dr1a-b $(\mathrm{n}=21)$} & \multirow{3}{*}{ Paranesti/Drama } & \multirow{3}{*}{ red } & aver & 17 & 41 & 2.9 & 9142 & 26,558 & 16 \\
\hline & & & $\min$ & 8 & 8 & 2 & 2431 & 1799 & 12 \\
\hline & & & $\max$ & 31 & 148 & 5.7 & 15,347 & 4384 & 24 \\
\hline \multirow{3}{*}{ Go1a-b $(n=26)$} & \multirow{3}{*}{ Gorgona/Xanthi } & \multirow{3}{*}{ blue-colorless } & aver & 322 & 4255 & 78 & 84 & 1003 & 89 \\
\hline & & & $\min$ & 78 & 1007 & 23 & 35 & 363 & 29 \\
\hline & & & $\max$ & 601 & 6462 & 207 & 251 & 1339 & 121 \\
\hline \multirow{3}{*}{ Go5a $(\mathrm{n}=8)$} & \multirow{3}{*}{ Gorgona/Xanthi } & \multirow{3}{*}{ pink-purple } & aver & 28 & 102 & 20 & 104 & 1291 & 47 \\
\hline & & & $\min$ & 13 & 30 & 5 & 4 & 962 & 9 \\
\hline & & & $\max$ & 49 & 205 & 60 & 298 & 1782 & 100 \\
\hline \multirow{3}{*}{ Go5b $(n=14)$} & \multirow{3}{*}{ Gorgona/Xanthi } & \multirow{3}{*}{ pink } & aver & 35 & 509 & 65 & 297 & 424 & 78 \\
\hline & & & $\min$ & 17 & 39 & 47 & 105 & 294 & 72 \\
\hline & & & $\max$ & 53 & 810 & 79 & 1082 & 494 & 87 \\
\hline \multirow{3}{*}{ Ik1a $(\mathrm{n}=24)$} & \multirow{3}{*}{ Ikaria isl. } & \multirow{3}{*}{ blue } & aver & 15 & 1263 & 116 & 223 & 4326 & 90 \\
\hline & & & $\min$ & 5 & 267 & 31 & 103 & 2710 & 68 \\
\hline & & & $\max$ & 54 & 4508 & 164 & 313 & 7324 & 114 \\
\hline \multirow{3}{*}{ Nx1-4 (n = 77) } & \multirow{3}{*}{$\begin{array}{c}\text { Naxos } \\
\text { isl./Kinidaros }\end{array}$} & \multirow{3}{*}{ blue-colorless } & aver & 58 & 594 & 22 & 214 & 3400 & 60 \\
\hline & & & $\min$ & 16 & 10 & 9 & 1 & 1377 & 42 \\
\hline & & & $\max$ & 208 & 3222 & 42 & 851 & 6361 & 184 \\
\hline \multirow{3}{*}{$\mathrm{Nx1b}(\mathrm{n}=14)$} & \multirow{3}{*}{$\begin{array}{c}\text { Naxos } \\
\text { isl./Kinidaros }\end{array}$} & \multirow{3}{*}{ purple } & aver & 64 & 520 & 22 & 43 & 4677 & 63 \\
\hline & & & $\min$ & 39 & 124 & 15 & 36 & 3324 & 55 \\
\hline & & & $\max$ & 199 & 848 & 31 & 48 & 6670 & 76 \\
\hline \multirow{3}{*}{$\mathrm{Nx} 5 \mathrm{~b}(\mathrm{n}=12)$} & \multirow{3}{*}{$\begin{array}{c}\text { Naxos } \\
\text { isl./Kinidaros }\end{array}$} & \multirow{3}{*}{ pink } & aver & 52 & 181 & 20 & 428 & 3096 & 45 \\
\hline & & & $\min$ & 17 & 60 & 14 & 274 & 2138 & 37 \\
\hline & & & $\max$ & 133 & 348 & 43 & 548 & 4716 & 52 \\
\hline \multirow{3}{*}{$\mathrm{Nx} 5 \mathrm{a}(\mathrm{n}=8)$} & \multirow{3}{*}{$\begin{array}{c}\text { Naxos } \\
\text { isl./Kavalaris }\end{array}$} & \multirow{3}{*}{ blue } & aver & 5 & 462 & 52 & 262 & 3706 & 87 \\
\hline & & & $\min$ & 2 & 238 & 43 & 227 & 3301 & 84 \\
\hline & & & $\max$ & 14 & 784 & 65 & 339 & 4268 & 90 \\
\hline
\end{tabular}


Sapphires from Naxos Island are characterized by high Fe concentrations (up to $6678 \mathrm{ppm}$ ), related to blue-colored domains. Ti is considerably lower (up to $966 \mathrm{ppm}$ ), with the exception of one colorless to blue corundum, where values up to $3222 \mathrm{ppm}$ were detected. Chromium in blue to colorless varieties is low and reaches values of up to $851 \mathrm{ppm}$ in grains with pink and purple hues. Vanadium content in the majority of the samples measured varies in the range of $20-40 \mathrm{ppm}$. Mg and Ga values range between 2-208 ppm and 42-184 ppm, respectively. The higher Ga concentrations occur in the metabauxite-hosted sapphires. Sapphires from Ikaria display high Fe and Ti values (up to 7324 ppm and $4508 \mathrm{ppm}$, respectively). $\mathrm{Cr}, \mathrm{Mg}$ and $\mathrm{V}$ values reach maximum values of up to 313, 54 and $164 \mathrm{ppm}$, respectively. Gallium shows elevated concentrations, up to $114 \mathrm{ppm}$. Figure 4 distinguishes different primary sources for the studied corundums based on the chromophore and genetic indicator elements. In the $(\mathrm{Cr}+\mathrm{V}) / \mathrm{Ga}$ versus Fe/Ti diagram (Figure 4a, [40,41]), the majority of the samples plot in the field of metamorphic corundum, exhibiting a large variation in $\mathrm{Fe} / \mathrm{Ti}$ ratios.
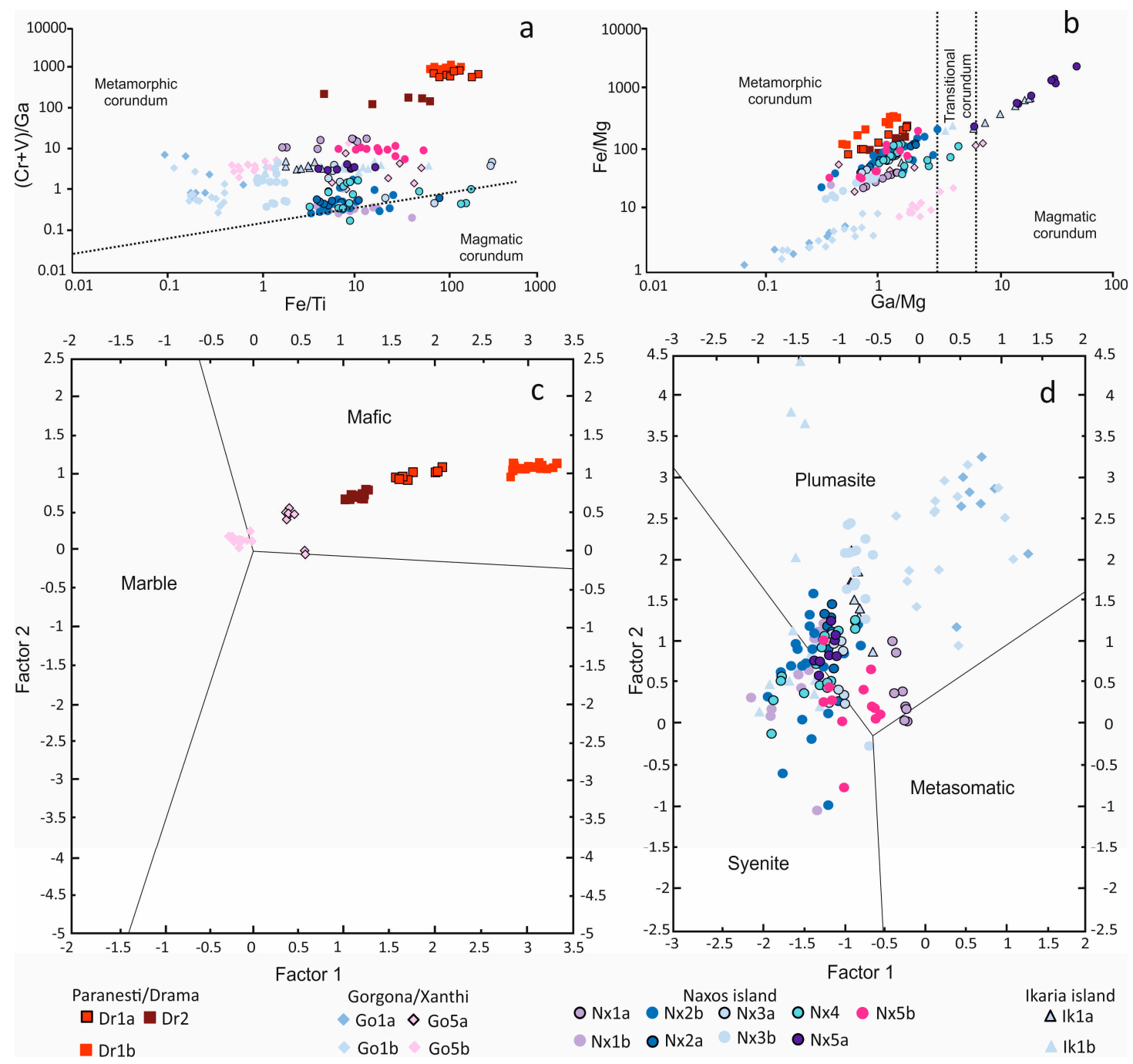

Figure 4. Greek corundum LA-ICP-MS analyses plotted on (a) $(\mathrm{Cr}+\mathrm{V}) / \mathrm{Ga}$ versus $\mathrm{Fe} / \mathrm{Ti}$ discrimination diagram separating the fields for magmatic and metamorphic corundums (adapted from Sutherland et al. [40] and Harris et al. [41]; (b) Fe/Mg versus $\mathrm{Ga} / \mathrm{Mg}$ discrimination separating the fields for magmatic, transitional and metamorphic corundums (adapted from Peucat et al. [42], Sutherland et al. [40] (both $\mathbf{a}$ and $\mathbf{b}$ are from Voudouris et al. [18]); (c) plot of Greek rubies (and Xanthi pink sapphires) within mafic rocks and marble field in discriminant factors diagram adapted after Giuliani et al. [43]; (d) plot of Greek sapphires within plumasite and syenite field in discriminant factors diagram adapted after Giuliani et al. [43]. 
Rubies from Paranesti/Drama show high $\mathrm{Cr} / \mathrm{Ga}$ and Fe/Ti ratios, followed by the pink and purple sapphires from Naxos Island. In the Fe/Mg versus $\mathrm{Ga} / \mathrm{Mg}$ plot (Figure 4b, [40,42]), most samples plot in the metamorphic corundum field, except for sapphires from the metabauxites of Naxos and Ikaria Islands. A few blue sapphires from Naxos Island and pink sapphires from Gorgona/Xanthi plot in the area of transitional corundum. In the discriminant factor diagrams of Giuliani et al. [43], the Paranesti rubies within the pargasitic schists, plot in the "mafic" field and pink corundums (e.g. sapphires because $\mathrm{Fe}>\mathrm{Cr}+\mathrm{V}$ ), from Xanthi in the "marble" field. In our study we considered pink corundum for which $\mathrm{Cr}+\mathrm{V}<\mathrm{Fe}$ as sapphires. From Figure 4c we can observe that the marble-hosted pink corundum from Xanthi (sample GO5b) plots in the marble area, while those of Go5a (pink purple) plot in the metasomatite field, suggesting that for sapphires the "marble" field (as defined for rubies) may extend to the right into the "metasomatic" field. Only part of the plumasitic sapphires from Naxos plot in the "plumasitic" field, the rest plotting in the "syenite" field (Figure 4d).

\subsection{Beryl}

The Greek pegmatites are mostly deficient in miarolitic cavities, and thus only contain matrix-embedded mineral crystals. Blue beryl crystals (var. aquamarine) up to $5 \mathrm{~cm}$ long are typical constituents of Naxos pegmatites both within the migmatitic dome as well as in pegmatites cross-cutting the surrounding metamorphic rocks (Figure $3 \mathrm{~g}-\mathrm{i}$ ).

\subsection{Jadeitite}

Jadeitite, a rock that is also termed jadeite "jade", consists almost entirely of the pyroxene mineral jadeite. Its green color is attributed to iron substituting for aluminum in the jadeite $\left[\mathrm{Na}\left(\mathrm{Al}, \mathrm{Fe}^{3+}\right) \mathrm{Si}_{2} \mathrm{O}_{6}\right]$ crystal structure [4]. Jadeitite together with omphacitite occurs within the Kampos mélange, Syros Island in contact relationship or enveloping eclogite $[27,44,45]$ as shown in Figure 5a,b. A production of polished jade axe heads on Syros took place at least since the Neolithic period [46].
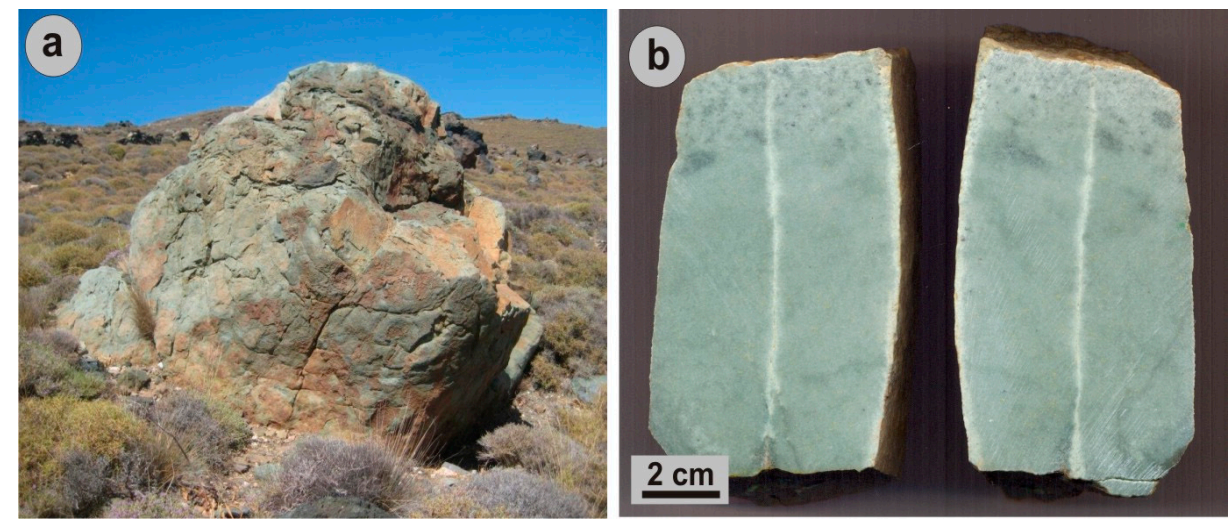

Figure 5. Field photographs (a) and hand specimens (b) of jadeitite from Kampos, Syros Island.

\section{4. $\mathrm{Al}_{2} \mathrm{SiO}_{5}$ Polymorphs}

Kyanite in blue, green, yellowish to orange colored crystals up to $20 \mathrm{~cm}$ long, is found in quartz \pm feldspar boudins intercalated within metapelites at Trikorfo, Thassos Island (Figure 6a-d) $[17,19,47]$. Orange kyanite also occurs in association with spessartine, and muscovite. Distinct dark blue color zoning is a common feature in the centre of some light blue kyanite; this color zoning can also be observed in some yellow kyanite. Microprobe analyses for orange kyanite indicate $\mathrm{MnO}$ up to $0.1 \mathrm{wt}$. \% contributing to the coloration of the crystals [19] and up to $1.5 \mathrm{wt}$. \% FeO. In a similar occurrence on Naxos Island in the Cyclades, kyanite forms up to $10 \mathrm{~cm}$ blue-colored crystals in quartz lenses and veins.

Mn-Andalusite (formerly viridine) in dark green-colored euhedral to subhedral crystals up to $7 \mathrm{~cm}$ is found in quartz-feldspar boudins (Figure 6e,f) at Trikorfo, Thassos Island. Mn-andalusite also 
occurs in orange kyanite-mica schists or in association with muscovite. Microprobe data revealed $\mathrm{Mn}_{2} \mathrm{O}_{3}$ contents, up to $2.90 \mathrm{wt}$. \% (Table 2). $\mathrm{Mn}^{3+}$ substituting for $\mathrm{Al}^{3+}$ in the mineral formula is responsible for the dark green color $[19,47]$.

\subsection{Epidote Group Minerals-Zoisite}

Mn-poor zoisite (var. thulite) and Mn-poor clinozoisite in calc-silicate layers at Trikorfo, Thassos Island, are intergrown with Mn-grossular and quartz (Figure $6 \mathrm{~g}-\mathrm{i}$ ). They form light pink to red colored translucent subhedral to euhedral crystals up to $10 \mathrm{~cm}$ long. Available electron microprobe data revealed low $\mathrm{Fe}_{2} \mathrm{O}_{3}$ content (1.5 wt. \%-2 wt. \%) and very low $\mathrm{Mn}_{2} \mathrm{O}_{3}$ values from 0.15 wt. \%-0.21 wt. \%, but enough to be responsible for the pink-red coloration $[19,47]$. Deep green colored epidote crystals, up to $10 \mathrm{~cm}$ long associated with quartz and garnets at Lefkopetra, near Kimmeria, Xanthi, within metasomatized granodiorite and gneiss-hosted exoskarn bodies (Figure 6j-1) are partly of gem-quality.
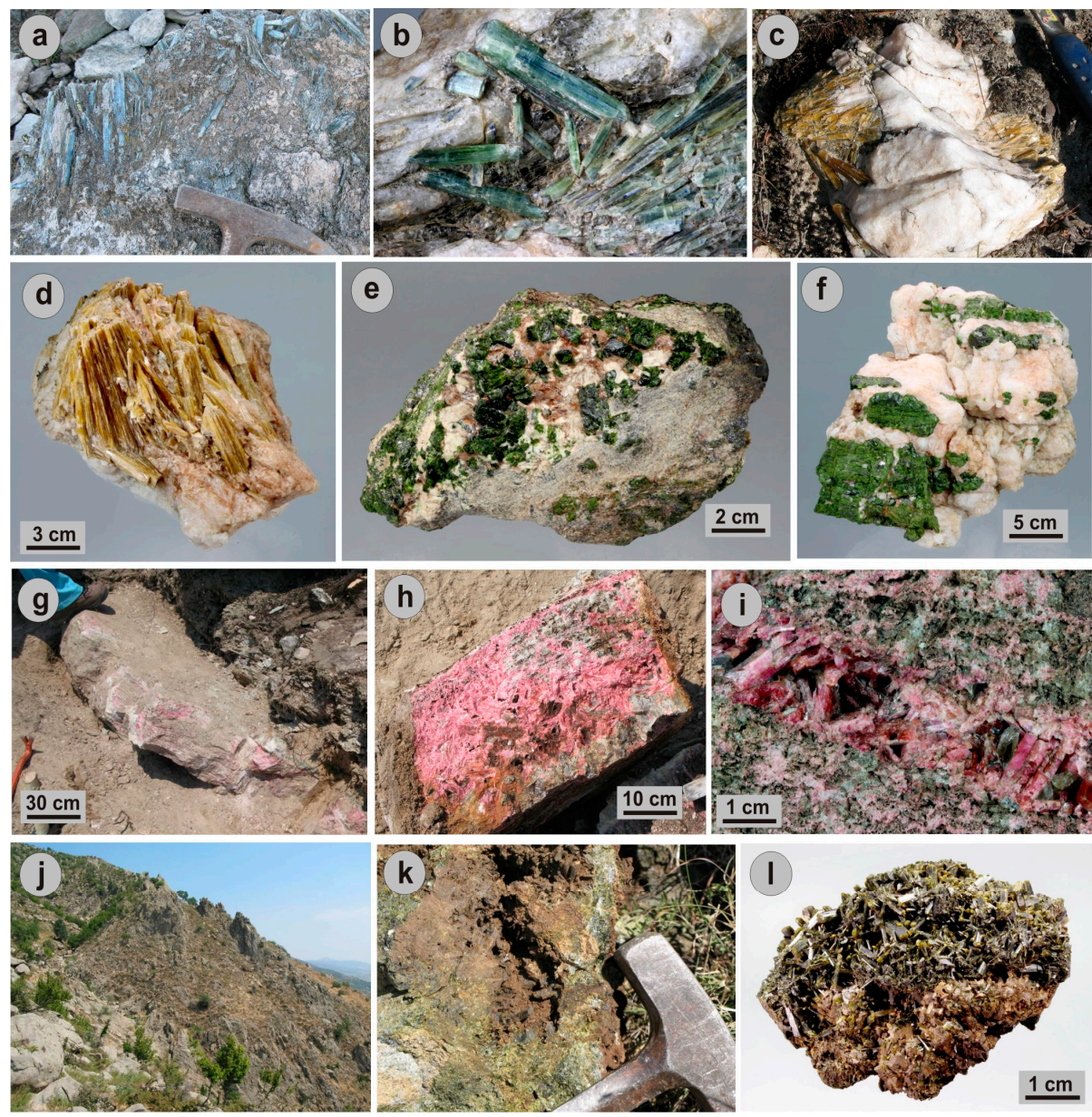

Figure 6. Field and hand specimens photographs demonstrating occurrences and crystals of gem-quality $\mathrm{Al}_{2} \mathrm{SiO}_{5}$-polymorphs and epidote-group minerals of Greece: (a-d) Blue, green to orange kyanite within metapelites and quartz veins at Trikorfo, Thassos Island; (e,f) Mn-rich andalusite (var. viridine) in quartz from Trikorfo, Thassos Island; (g-i) Pink-red, Mn-bearing zoisite/clinozoisite from Trikorfo, Thassos Island. (j) Epidote-bearing skarn of Lefkopetra, Kimmeria/Xanthi. Granodiorite is at the front of the photo; (k,1) Green epidote crystals associated with andradite from Lefkopetra; Photographs $6 \mathrm{~b}, \mathrm{~d}, \mathrm{e}, \mathrm{f}, \mathrm{i}, \mathrm{l}$ are courtesy of Berthold Ottens.

\subsection{Garnets}

Spessartine and Mn-grossular are crystallized within andalusite-kyanite schists and in the thulite-bearing calc-silicate layers of Trikorfo respectively $[17,19,47]$. Spessartine from quartz-muscovite 
veins within mica schists forms translucent, orange-colored euhedral crystals up to $1 \mathrm{~cm}$ and of gem-quality (Figure 7a,b). Electron microprobe analyses of spessartine indicate MnO contents up to 42.9 wt. \% (Table 2). Mn-bearing grossular from the calc-silicate layers form euhedral yellowish crystals of gem-quality in close association with pink-to red colored Mn-zoisite and quartz. MnO content ranges from 1.9 wt. \%-2.4 wt. \% (Table 2).
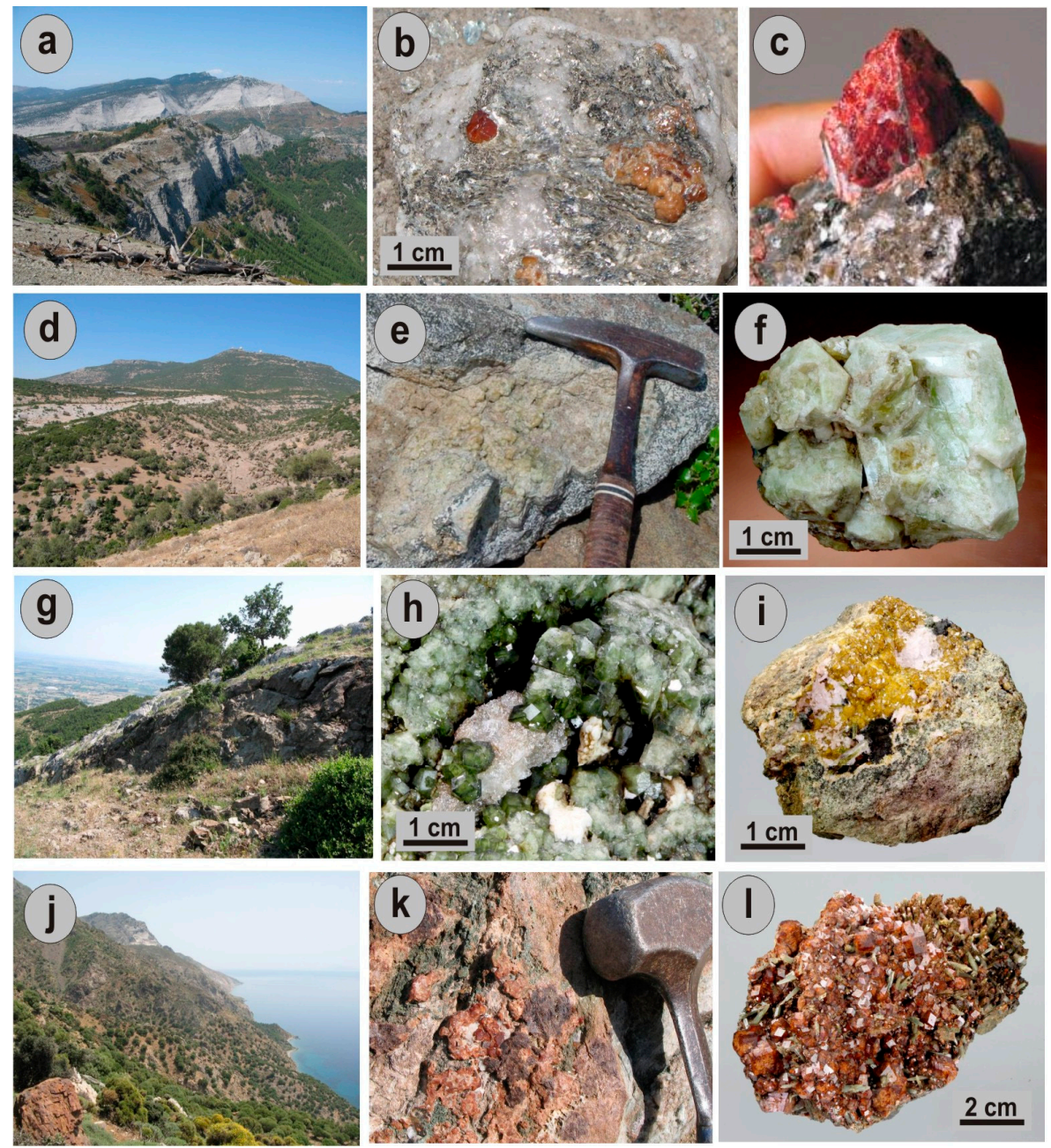

Figure 7. Field and hand specimens photographs demonstrating gem garnet occurrences/crystals of Greece: (a) alternating marbles and metapelites at Trikorfo, Thassos Island. Metapelites host spessartine together with other Mn-bearing silicates; (b) spessartine crystals associated with muscovite within quartz matrix; (c) spessartine within braunite-phlogopite bearing skarn from Thapsana. Paros Island; (d) Maronia skarn at the interface between marbles and the Maronia pluton (half right part of the photograph); (e) grossular crystals in contact with the Maronia monzogabbro; (f) partly transparent pale green grossular crystals from the Maronia skarn; (g) andradite-bearing wollastonitic skarn in contact with marbles, Kimmeria, Xanthi; (h) Green andradite and calcite from Kimmeria, Xanthi; (i) yellow andradite within amphibolite, Kimmeria, Xanthi; (j) Panoramic view of skarn at Dikeon Mt, southern Kos Island; (k) orange andradite and diopside from the Dikeon Mt skarn, Kos Island; (1) red-brown andradite with green quartz from Avessalos, Serifos Island. Photographs $7 \mathbf{f}, \mathbf{h}, \mathbf{i}, \mathbf{l}$ are courtesy of Berthold Ottens.

Deep red colored spessartine crystals up to $3 \mathrm{~cm}$ at Paros Island/Cyclades, are related to Mn-bearing skarn occurrences at Thapsana (Figure 7c). Spessartine at Thapsana contains up to 34.4 wt. \% MnO and is associated with rhodonite and Mn-oxides [48]. Garnet is also a major constituent and represented by several varieties at Maronia, Kimmeria, Kresti, Kos and Serifos skarns. The Maronia skarn (Figure 7d) includes dark green-colored Ti-Cr andradite-grossular up to $1 \mathrm{~cm}$, which postdates crystallization of 
earlier black-colored schorlomite-uvarovite-kimzeyite solid solutions [13]. Late pale green, brown to orange grossular-andradite solid solutions reach sizes up to $5 \mathrm{~cm}$ (Figure $7 \mathrm{e}, \mathrm{f}$ ). Ti-bearing brown grossular-andradite contains up to $4.6 \mathrm{wt}$. $\% \mathrm{TiO}_{2}$. Transparent specimens with shiny dodecahedron faces are of gem-quality. A wide spectrum of colors in andradite-grossular garnets also occurs at Kimmeria where dark green-, brown-, yellow- to orange-colored garnets (up to $3 \mathrm{~cm}$ ) occur (Figure $7 \mathrm{~g}-\mathrm{i}$ ). Orange-colored grossular contains up to $1.15 \mathrm{wt}$ \% $\mathrm{MnO}$, whereas dark green-colored andradite-grossular solid solutions are characterized by elevated Ti contents (up to $2.86 \mathrm{wt}$. \% $\mathrm{TiO}_{2}$; Table 2).

Red-brown Mn-bearing andradite-grossular is present at Kresti in Drama (with up to 3.6 wt. \% $\mathrm{MnO}$ ) and at Kos Island (with up to $1.1 \mathrm{wt}$. $\% \mathrm{MnO}$ and $1 \mathrm{wt} . \% \mathrm{TiO}_{2}$, Table 2), where they reach spectacular sizes of up to $20 \mathrm{~cm}$ (Figure 7j,k). The Serifos andradites are famous due to their zonal growth with colors ranging from deep brown to orange. The Agia Marina and Avessalos areas at Serifos are characterized by splendid occurrences of red-brown, locally transparent andraditic garnets in massif garnetitic skarns (Figure 7l). The garnets (up to $5 \mathrm{~cm}$ in size) accompany quartz and hematite in hedenbergitic skarn. Rodingitized gabbros at Evros, Evia, Larissa and Othrys Mesozoic ophiolites host gem-quality orange to brown grossular (hessonite), vesuvianite and diopside crystals up to $2 \mathrm{~cm}$ long $[17,49]$.

\subsection{Quartz}

Quartz is found in an enormous variety of forms and colors from alpine-type fissures, granite-hosted miarolitic cavities and/or quartz veins, skarn-carbonate replacement deposits and volcanic-hosted epithermal environments $[14,17,35,50,51]$. Famous localities of gem-quality alpine-type quartz include the Attica and Drama districts, as well as Evia, Ios, Thassos and Crete Islands (Figures 2 and $8 \mathrm{a}-\mathrm{c}$ ). Crystals reach sizes up to $40 \mathrm{~cm}$. Smoky quartz, black quartz (morion), rock crystal, amethyst, chloritized quartz and rutilated quartz are among the varieties found throughout Greece.

Quartz crystals up to $50 \mathrm{~cm}$, in colorless, smoky and black varieties (morion) fill miarolitic cavities in aplitic granites at Samothraki Island (Figure 8d). Colorless quartz crystals (up to $10 \mathrm{~cm}$ ) also occur in quartz veins cross-cutting granitoids at Samothraki, Kimmeria, Maronia/Rhodopi and Tinos Island.

Quartz is a very common mineral in the skarns of Serifos, Kimmeria/Xanthi and Kresti/Drama. Combinations of amethyst and green quartz (prase) forming sceptre growths at Serifos are worldwide unique specimens. Green-colored (due to actinolite inclusions) quartz crystals, are also developed within wollastonite skarn, at both Kimmeria and Kresti.

The Avessalos area at Serifos Island is one of the best sites in the world in respect to its green quartz (prase) $[12,13,52]$. The area is characterized by a garnetitic and hedenbergitic skarn and by the development of huge geodes filled by prograde and retrograde skarn minerals. At Neroutsika location of Avessalos, two forms of prase occur (Figure 8e,f): the first variety refers to very deep green colored crystals accompanied by hematite roses. The second variety refers to double-colored crystals of prase-amethyst. The transition between these two crystals is abrupt within the same crystal, where prase occurs at the base and amethyst at the top of the crystal. The amethysts are transparent and of gem-quality $[15,16]$. In the southern part of the Avessalos area, rare combinations of scepter-shaped crystals contain both prase and amethyst. These crystals commonly comprise a lower prase part that evolves upwards into amethyst and further upwards again into prase. These alternations can be remarked even within a single crystal [13]. Gem-quality quartz, in crystals up to $60 \mathrm{~cm}$ also occurs at the carbonate-replacement deposits of Chalkidiki [53]. 
Table 2. Representative EPMA of various gem-quality minerals from Greece: Andradite-grossular, Kimmeria (1-2); Andradite-grossular, Maronia (3-4); Andradite-Grossular, Kos Island (5); Grossular, Thassos (6-8); Spessartine, Thassos (9-10); Zoisite, Thassos (11-12); Mn-andalusite, Thassos (13-14); Orange kyanite, Thassos (15-16); Blue kyanite, Thassos (17).

\begin{tabular}{|c|c|c|c|c|c|c|c|c|c|c|c|c|c|c|c|c|c|}
\hline $\mathbf{W t} \%$ & 1 & 2 & 3 & 4 & 5 & 6 & 7 & 8 & $9^{*}$ & $10^{*}$ & 11 & 12 & $13^{*}$ & $14^{*}$ & $15^{*}$ & $16^{*}$ & $17^{*}$ \\
\hline $\mathrm{SiO}_{2}$ & 39.77 & 37.73 & 38.22 & 39.03 & 38.05 & 38.97 & 39.05 & 39.31 & 35.71 & 34.31 & 39.23 & 39.11 & 36.08 & 36.07 & 36.40 & 36.68 & 36.71 \\
\hline $\mathrm{Al}_{2} \mathrm{O}_{3}$ & 20.21 & 6.02 & 18.79 & 19.60 & 8.17 & 21.74 & 21.88 & 22.20 & 20.78 & 23.40 & 32.71 & 32.11 & 58.98 & 58.24 & 61.90 & 61.29 & 61.18 \\
\hline $\mathrm{MgO}$ & $\mathrm{bd}$ & 0.23 & 0.64 & 0.39 & 0.19 & 0.14 & 0.17 & 0.12 & 0.31 & 0.41 & 0.02 & 0.10 & 0.11 & 0.16 & bd & bd & 0.01 \\
\hline $\mathrm{FeO}$ & 3.68 & 19.28 & 5.62 & 4.40 & 19.00 & 1.03 & 1.08 & 0.61 & 0.08 & 0.52 & - & - & - & - & 0.76 & 1.52 & 1.49 \\
\hline $\mathrm{Fe}_{2} \mathrm{O}_{3}$ & - & - & - & - & - & - & - & - & - & - & 1.55 & 2.01 & 1.93 & 2.14 & - & - & - \\
\hline $\mathrm{Cr}_{2} \mathrm{O}_{3}$ & 0.05 & 0.73 & $\mathrm{bd}$ & 0.09 & - & 0.03 & $\mathrm{bd}$ & 0.04 & - & - & - & - & - & - & - & - & - \\
\hline $\mathrm{MnO}$ & 1.15 & 0.10 & 0.20 & 0.07 & 1.14 & 1.90 & 2.18 & 2.42 & 42.87 & 40.40 & - & - & - & - & 0.08 & 0.11 & 0.02 \\
\hline $\mathrm{Mn}_{2} \mathrm{O}_{3}$ & - & - & - & - & - & - & - & - & - & - & 0.15 & 0.21 & 2.50 & 2.89 & - & - & - \\
\hline $\mathrm{CaO}$ & 34.55 & 33.59 & 34.92 & 35.40 & 32.10 & 36.00 & 35.76 & 35.39 & 0.55 & 0.93 & 24.78 & 24.73 & 0.02 & bd & $\mathrm{bd}$ & bd & 0.03 \\
\hline $\mathrm{Na}_{2} \mathrm{O}$ & - & 0.26 & - & - & $\mathrm{bd}$ & 0.01 & 0.01 & bd & bd & $\mathrm{bd}$ & bd & bd & 0.00 & 0.02 & 0.04 & $\mathrm{bd}$ & 0.04 \\
\hline $\mathrm{TiO}_{2}$ & 0.03 & 2.86 & 1.10 & 0.13 & 0.92 & 0.42 & 0.25 & 0.12 & 0.09 & 0.05 & 0.02 & 0.04 & 0.01 & 0.02 & 0.02 & 0.01 & $\mathrm{bd}$ \\
\hline Total & 99.39 & 100.54 & 99.49 & 99.11 & 99.57 & 100.23 & 100.37 & 100,21 & 100.39 & 100.02 & 98.44 & 98.31 & 99.64 & 99.52 & 99.20 & 99.62 & 99.48 \\
\hline \multicolumn{5}{|c|}{ Formulae } & \multicolumn{3}{|c|}{$24(\mathrm{O})$} & & & & \multicolumn{3}{|c|}{8 cations } & \multicolumn{3}{|c|}{$5(\mathrm{O})$} & \\
\hline $\mathrm{Si}$ & 6.076 & 6.032 & 5.856 & 5.974 & 6.094 & 5.872 & 5.876 & 5.920 & 5.880 & 5.619 & 2.970 & 2.970 & 0.993 & 0.996 & 0.995 & 1.001 & 1.003 \\
\hline $\mathrm{Al}$ & 3.640 & 1.134 & 3.392 & 3.536 & 1.542 & 3.860 & 3.880 & 3.940 & 4.033 & 4.517 & 2.918 & 2.874 & 1.913 & 1.895 & 1.994 & 1.973 & 1.971 \\
\hline $\mathrm{Mg}$ & 0.000 & 0.054 & 0.148 & 0.088 & 0.046 & 0.032 & 0.038 & 0.026 & 0.076 & 0.100 & 0.003 & 0.011 & 0.005 & 0.007 & 0.007 & 0.000 & 0.000 \\
\hline $\mathrm{Fe}^{2+}$ & 0.276 & 0.554 & 0.078 & 0.086 & 0.496 & 0.000 & 0.000 & 0.000 & 0.011 & 0.071 & 0.000 & 0.000 & 0.000 & 0.000 & 0.017 & 0.034 & 0.033 \\
\hline $\mathrm{Fe}^{3+}$ & 0.196 & 2.024 & 0.642 & 0.478 & 2.048 & 0.296 & 0.312 & 0.190 & 0.000 & 0.000 & 0.088 & 0.115 & 0.040 & 0.045 & 0.000 & 0.000 & 0.000 \\
\hline $\mathrm{Cr}^{3+}$ & 0.003 & 0.092 & 0.000 & 0.010 & - & 0.004 & 0.000 & 0.002 & - & - & - & - & - & - & - & - & - \\
\hline $\mathrm{Mn}^{2+}$ & 0.148 & 0.014 & 0.026 & 0.010 & 0.154 & 0.242 & 0.278 & 0.308 & 5.979 & 5.604 & 0.000 & 0.000 & 0.000 & 0.000 & 0.002 & 0.003 & 0.000 \\
\hline $\mathrm{Mn}^{3+}$ & 0.000 & 0.000 & 0.000 & 0.000 & - & - & - & - & 0.000 & 0.000 & 0.010 & 0.000 & 0.052 & 0.061 & 0.000 & 0.000 & 0.000 \\
\hline $\mathrm{Ca}$ & 5.658 & 5.752 & 5.732 & 5.804 & 5.508 & 5.812 & 5.764 & 5.710 & 0.097 & 0.163 & 2.010 & 2.013 & 0.001 & 0.000 & 0.000 & 0.000 & 0.000 \\
\hline $\mathrm{Na}$ & 0.000 & 0.011 & 0.000 & 0.000 & - & 0.000 & 0.000 & 0.000 & 0.000 & 0.000 & 0.000 & 0.000 & 0.000 & 0.002 & 0.002 & 0.000 & 0.011 \\
\hline $\mathrm{Ti}$ & 0.004 & 0.344 & 0.126 & 0.014 & 0.110 & 0.048 & 0.028 & 0.014 & 0.011 & 0.006 & 0.001 & 0.002 & 0.000 & 0.000 & 0.000 & 0.000 & 0.000 \\
\hline
\end{tabular}

$(-)=$ not analyzed; bd = below detection. Analyses marked with $\left(^{*}\right)$ are from Tarantola et al. [19] (this volume). 
Amethyst is the main quartz variety of gem-quality in the volcanic rock-hosted epithermal environments in Greece. It occurs at Kornofolia/Evros area, in Sapes/Rhodopi region and in Lesvos and Milos Islands in epithermal veins accompanying calcite, and/or adularia and barite [13,35]. At Sapes, amethyst occurs in massive form within crustiform banded quartz-chalcedony veins, however cavities in the veins may host deep purple crystals up to $2 \mathrm{~cm}$. In Milos and Kornofolia, well-developed amethyst crystals (up to $2 \mathrm{~cm}$ ) occur as open space filling in the centre of veins cross-cutting propylitic and sericitic altered volcanics (Figure 8g,h). At Megala Therma, Lesvos Island, amethyst is prismatic, up to $10 \mathrm{~cm}$ in length and displays sceptre and window growths and shares similarities to the Mexican and Sardinian occurrences.
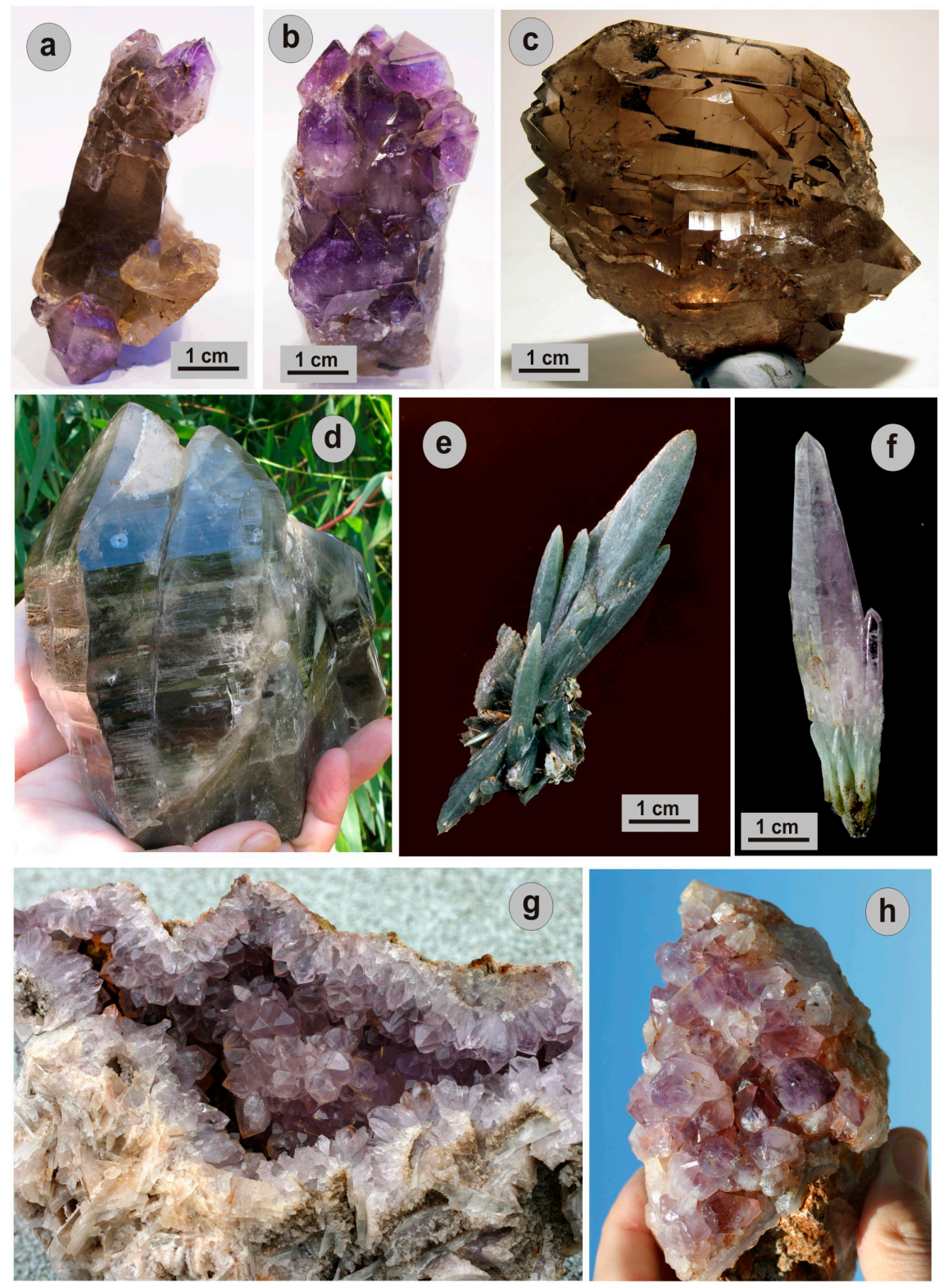

Figure 8. Hand specimens illustrating the gem quartz crystals of Greece: $(\mathbf{a}, \mathbf{b})$ smoky quartz and amethyst from Dassoto, Drama; (c) smoky quartz from Koskina, Evia Island; (d) morion from Samothraki Island; (e) green quartz from Avessalos, Serifos Island; (f) amethyst on green quartz from Avessalos, Serifos Island; (g) amethyst on barite from Chondro Vouno, Milos Island; (h) amethyst from Kornofolia, Evros district. Photographs $8 \mathrm{e}, \mathrm{f}$ are courtesy of Berthold Ottens. 
The oxygen isotopic composition of quartz from the various geological environments has been analyzed in hand-picked crystals and the results are presented in Table 3. Quartz from the alpine-type fissures yield isotopic $\delta^{18} \mathrm{O}$ values between $9.4 \%$ and $23.7 \%$ o (Figure 9 ).

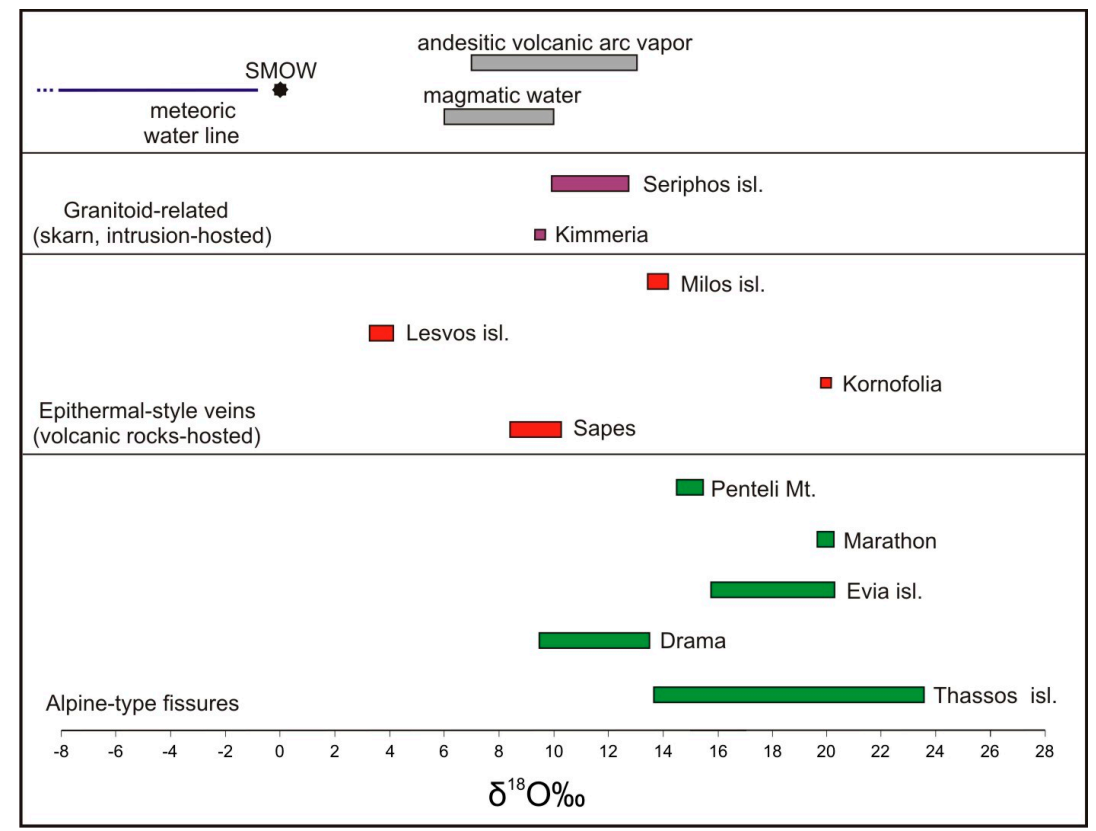

Figure 9. $\delta^{18} \mathrm{O}$ values of quartz varieties from Greece. The values for magmatic water and andesitic volcanic arc vapor are from Taylor [54] and Giggenbach [55], respectively.

Table 3. Oxygen isotope composition of quartz from various geological settings in Greece ( $\mathfrak{\delta}$ values in $\%$ relative to SMOW).

\begin{tabular}{cccc}
\hline Sample & Locality & Type & $\mathbf{\delta}^{\mathbf{1 8}} \mathbf{O}_{\mathbf{Q t z}} \mathbf{( \% \mathbf { o } )}$ \\
\hline & & Alpine-type fissures & \\
TH1 & Thassos Island & Colorless Qtz, Tessin habit & 18.44 \\
TH2 & Thassos Island & Smoky Qtz, Tessin habit & 13.77 \\
TH3 & Thassos Island & Colorless Qtz, skeletal habit & 18.82 \\
TH4 & Thassos Island & Colorless Qtz, sceptre, prismatic habit & 21.41 \\
TH5 & Thassos Island & Smoky Qtz, sceptre, prismatic habit & 23.66 \\
TH6 & Thassos Island & Smoky Qtz, Tessin habit & 14.56 \\
TH7 & Thassos Island & Choritized Qtz, Tessin habit & 18.11 \\
TH8 & Thassos Island & Smoky Qtz, Tessin habit & 14.66 \\
KN1 & Drama & Amethyst, prismatic habit & 13.38 \\
KN2 & Drama & Amethyst, prismatic habit & 13.36 \\
KN3 & Drama & Morion, Tessin habit & 10.63 \\
KN4 & Drama & Morion, Tessin habit & 10.83 \\
AL1 & Evia Island & Colorless Qtz, prismatic habit & 16.80 \\
AL2 & Evia Island & Smoky Qtz, prismatic habit & 20.77 \\
AL2B & Evia Island & Smoky Qtz, prismatic habit & 15.74 \\
AL3 & Evia Island & Smoky Qtz, prismatic habit & 16.04 \\
AL4 & Evia Island & Smoky Qtz, prismatic habit & 18.56 \\
AL5 & Evia Island & Colorless Qtz, prismatic habit & 20.15 \\
MA1 & Marathon, Attica & Amethyst, prismatic habit & 20.74 \\
MA2 & Marathon, Attica & Smoky Qtz, prismatic habit & 19.43 \\
PEN1 & Penteli Mt, Attica & Colorless Qtz, prismatic habit & 15.37 \\
PEN2 & Penteli Mt, Attica & Smoky Qtz, prismatic habit & 14.14 \\
\hline
\end{tabular}


Table 3. Cont.

\begin{tabular}{cccc}
\hline Sample & \multicolumn{1}{c}{ Locality } & \multicolumn{1}{c}{ Type } & $\boldsymbol{\delta}^{\mathbf{1 8}} \mathbf{O}_{\mathbf{Q t z}} \mathbf{( \% \mathbf { o o }}$ \\
\hline \multicolumn{4}{c}{ Epithermal veins } \\
SH1 & Sapolcanic rock-hosted) & \\
SH2 & Sapes, Rhodopi & Smoky Qtz & 10.49 \\
KIR1 & Kirki, Evros & Amethyst & 8.24 \\
SF2 & Soufli, Evros & Amethyst & 19.10 \\
LS2 & Lesvos Island & Amethyst & 20.54 \\
LS3 & Lesvos Island & Amethyst & 3.33 \\
LS5 & Lesvos Island & Colorless Qtz & 2.68 \\
M1 & Milos Island & Colorless Qtz, Muzo habit & 4.13 \\
M2 & Milos Island & Amethyst & 14.12 \\
& Granitoid-related (skarn, intrusion-hosted) & 13.41 \\
KIM1 & Kimmeria, Xanthi & Colorless Qtz & \\
\hline
\end{tabular}

In the absence of fluid inclusion temperature results, the composition of the fluid in equilibrium with the quartz crystals on the basis of the fractionation equilibrium equation of Sharp et al. [56], cannot be estimated. However, the available data, especially for sceptered quartz crystals from the Rhodope area (Dassoto and Thassos Island), indicate an increase in $\delta^{18} \mathrm{O}$ values from the basal Tessin-habit parts of the crystals, towards the amethystine or clear and prismatic-habit sceptres on the upper parts of the crystal. Melfos and Voudouris [57] suggested that smoky quartz and amethyst at Dassoto were formed under different conditions due to mixing of carbonic metamorphic fluids with meteoric waters during the exhumation of the Rhodope core complex. The presence of hematite and pyrite within smoky quartz indicates $f \mathrm{~S}_{2} / f \mathrm{O}_{2}$ conditions at the hematite/pyrite buffer, which were followed by more oxidizing conditions necessary for trivalent Fe to be incorporated into the quartz structure and to the crystallization of amethyst [57].

Similarly, the Thassos colorless and smoky quartz sceptre, display $\delta^{18} \mathrm{O}$ values between 21.4 and $23.66 \%$, heavier than the basal Tessin habit quartz crystals (values from $13.8 \%$ o to $18.8 \%$, Table 3 ), thus suggesting involvement of two different fluid types in the crystallization of quartz. This is in accordance to the fluid inclusion results of Bitte et al. [58], who suggested for the quartz crystals from Thassos Island, a continuous event at ductile-brittle to brittle conditions from 360 to $170{ }^{\circ} \mathrm{C}$ and at pressures lower than $2 \mathrm{MPa}$. Carbonic-rich fluids are replaced by surficial fluids, derived from evaporated sea-water during the final period of exhumation.

Smoky, chloritized and colorless quartz crystals in the Attico-Cycladic massif (Evia Island, Penteli Mt including Marathon area) display a similar range of $\delta^{18} \mathrm{O}$ values (from 14.1 to $20.8 \%$ ) to those from Thassos (Table 3, Figure 9). According to Tarantola et al. [59], metamorphic and basinal fluids were trapped in Evia Island quartz crystals during exhumation of the Attic-Cycladic metamorphic complex. Mineral inclusions of biotite and chlorite in quartz indicate continuous crystallization from 430 to $250{ }^{\circ} \mathrm{C}$.

Volcanic-rock hosted amethysts yield isotopic $\delta^{18} \mathrm{O}$ values between $3.3 \%$ ond $20.5 \%$ o (Figure 9; see also Voudouris et al. [35]. Those from Kassiteres-Sapes show $\delta^{18} \mathrm{O}$ values of 8.2 to $10.5 \%$ o. The amethyst at Kornofolia, Evros district, yielded the highest $\delta^{18} \mathrm{O}$ values $(20.5 \%$ o) and those from Lesvos the lowest $\delta^{18} \mathrm{O}$ value of all amethysts analysed (3.3\%o). Finally, the Milos amethyst have $\delta^{18} \mathrm{O}$ values of 13.4 and $14.1 \%$. Based on fluid inclusion data, Voudouris et al. [35] suggested that most $\delta^{18} \mathrm{O}$ values correspond to a mixing of magmatic and oceanic (and/or meteoric) water, with the highest magmatic component in Kornofolia and the lowest in Lesvos Island.

Quartz from a granite-hosted vein at Kimmeria, Xanthi yielded a $\delta^{18} \mathrm{O}$ value of $9.49 \%$. The isotopic signature of prase at Serifos skarn is comparable to those of quartz samples from different assemblages of the skarn zone at Serifos, but amethyst displays a significantly lighter isotopic signature [52]. 


\subsection{Chalcedony and Other Silica Rich Varieties}

Blue agate occurs in veins cross-cutting dacitic lavas and/or as loose fragments at Aetochori, Evros district (Figure 10a) [17]. Agate with various colors is also found in the volcanic environments of Lefkimi/Evros (Figure 10b), and Limnos Island. Chalcedony is present at Kornofolia/Evros and at Petsofas/Lesvos, where it forms typical botryoidal and stalactitic aggregates up to $10 \mathrm{~cm}$, varying in color from pale to deep blue and pink to purple (Figure 10c,d). Red jasper occurs in the Sapes area in the form of up to $40 \mathrm{~cm}$ thick horizons hosted in smectite-altered pyroclastics (Figure 10e,f) [60]. Jasper and agate from Lesvos Island have been described by Thewalt et al. [61].
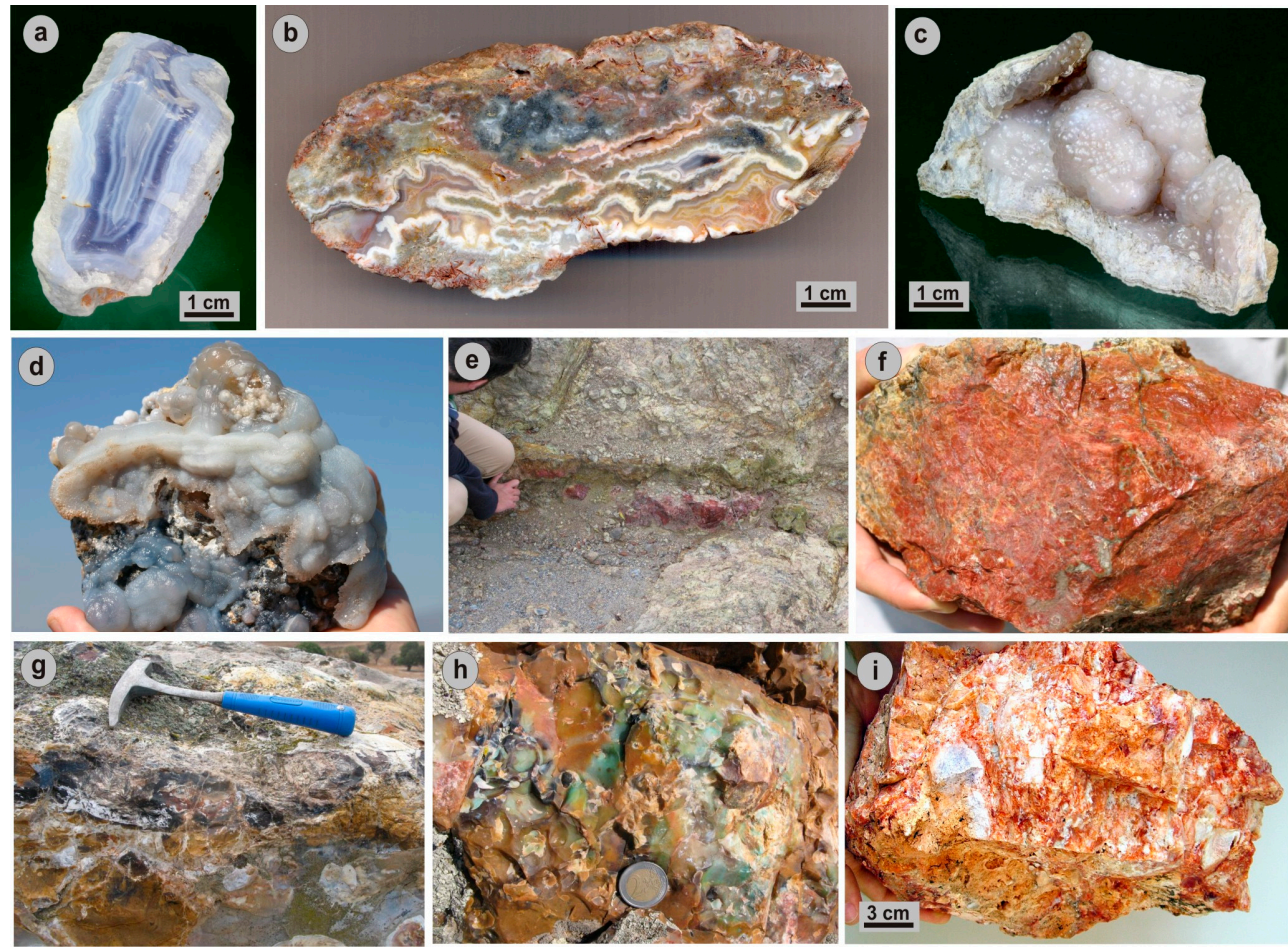

Figure 10. Field and hand specimens photographs demonstrating gem microcrystalline and amorphous silica varieties from Greece: (a) blue agate from Aetochori, Evros; (b) agate from Lefkimi, Evros; (c) chalcedony from Kornofolia, Evros; (d) blue chalcedony from Petsofas, Lesvos Island; (e) red jasper layer within smectite-altered pyroclastics, Sapes, Rhodopi; (f) red jasper from Sapes, Rhodopi; (g,h) brown and green opalized wood from Moudros, Limnos Island; (i) red opal from Agioi Theodoroi, Milos Island. Photographs 10a,c courtesy Berthold Ottens.

\subsection{Opal}

Opal occurs in several varieties and colors (deep red, yellow, black, orange and green) at Lesvos and Limnos Islands being a constituent of fossilized wood [13,62-64], as well as at various localities at Evros, Milos, Limnos and Lesvos Islands, where it is considered to be part of either silica sinters or steam-heated alteration zones. At the Moudros area, Limnos Island several horizons of opaline silicification within the pyroclastic rocks host opalized wood $[64,65]$. These horizons represent either thin-bedded, lacustrine-fluviatile intercalations between the pyroclastic formations and were deposited during erosional periods that lasted between the volcanic activity phases, or true silica sinter deposition. In some places the fossiliferous horizons overly an alunitic alteration zone and hydrothermal breccias rich in natroalunite occur. In other cases the opaline horizon is intercalated between fresh to weak argillicaly altered rocks. Silicification within the horizons varies from red, green, white, to black colored, the white color resulting from total depletion in iron oxides (Figure $10 \mathrm{~g}-\mathrm{i}$ ). Representative X-ray powder diffraction diagrams from Greek opals are given in Figure 11, demonstrating the transformation of opal-C to quartz in some samples. 

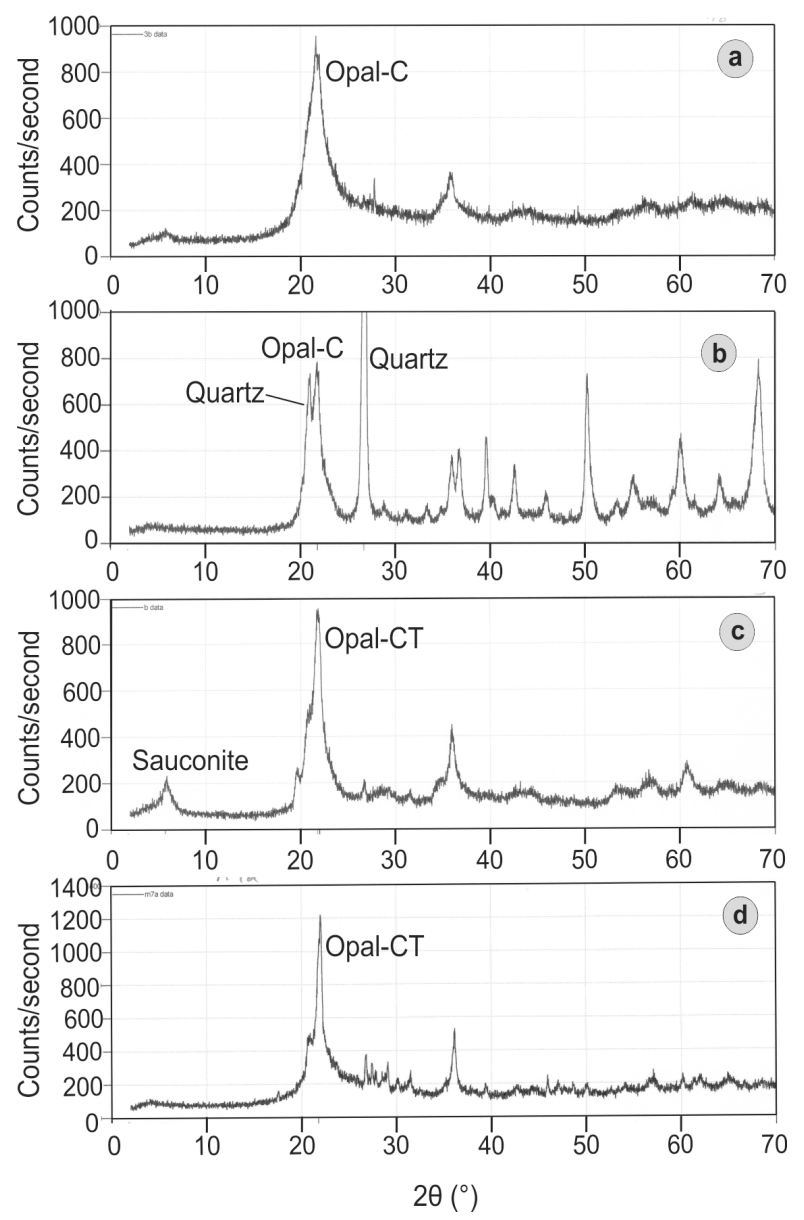

Figure 11. X-ray powder diffraction diagrams of various Greek opals $(\mathbf{a}, \mathbf{b})$ brown-orange opal-C and quartz from Lykofi Evros; (c) green opal-CT (color due to sauconite admixtures) from Sapes; (d) red-brown opal-CT from Moudros, Limnos Island.

\subsection{Feldspars}

Gem-quality albite is present as idiomorphic transparent crystals, up to $6 \mathrm{~cm}$ in size, grown onto clear and smoky quartz crystals from Evia and Crete Islands (Figure 12a,b). Adularia constitutes well-developed crystals up to $3 \mathrm{~cm}$ in size, which occupy alpine-type fissures along with quartz mainly from Evia and Thassos areas.

\subsection{Titanite}

Titanite in large yellow crystals (up to $3 \mathrm{~cm}$ ), accompanies zoisite-bearing calc-silicate layers within amphibolites of the Rhodope massif at Therapio, Evros [66]. Green titanite crystals up to $5 \mathrm{~cm}$ long at Syros Island, belongs to the retrograde mineral assemblage of eclogites. Titanite in honey colored crystals up to $1 \mathrm{~cm}$, accompany orthoclase and schorlomite in the Maronia endoskarn. Finally, yellow/green colored titanite is associated with adularia in amphibolite-hosted fissures at Thassos Island [51] (Figure 12c). All localities include locally transparent gemmy-material.

\subsection{Vesuvianite}

The endoscarns from Kimmeria and Maronia host large, up to $10 \mathrm{~cm}$ long, partly facetable pale green colored vesuvianite crystals (Figure 12d). Violet-colored vesuvianite in crystals up to $1 \mathrm{~cm}$ occur in rodingitized gabbros at Kymi, Evia Island [17]. 

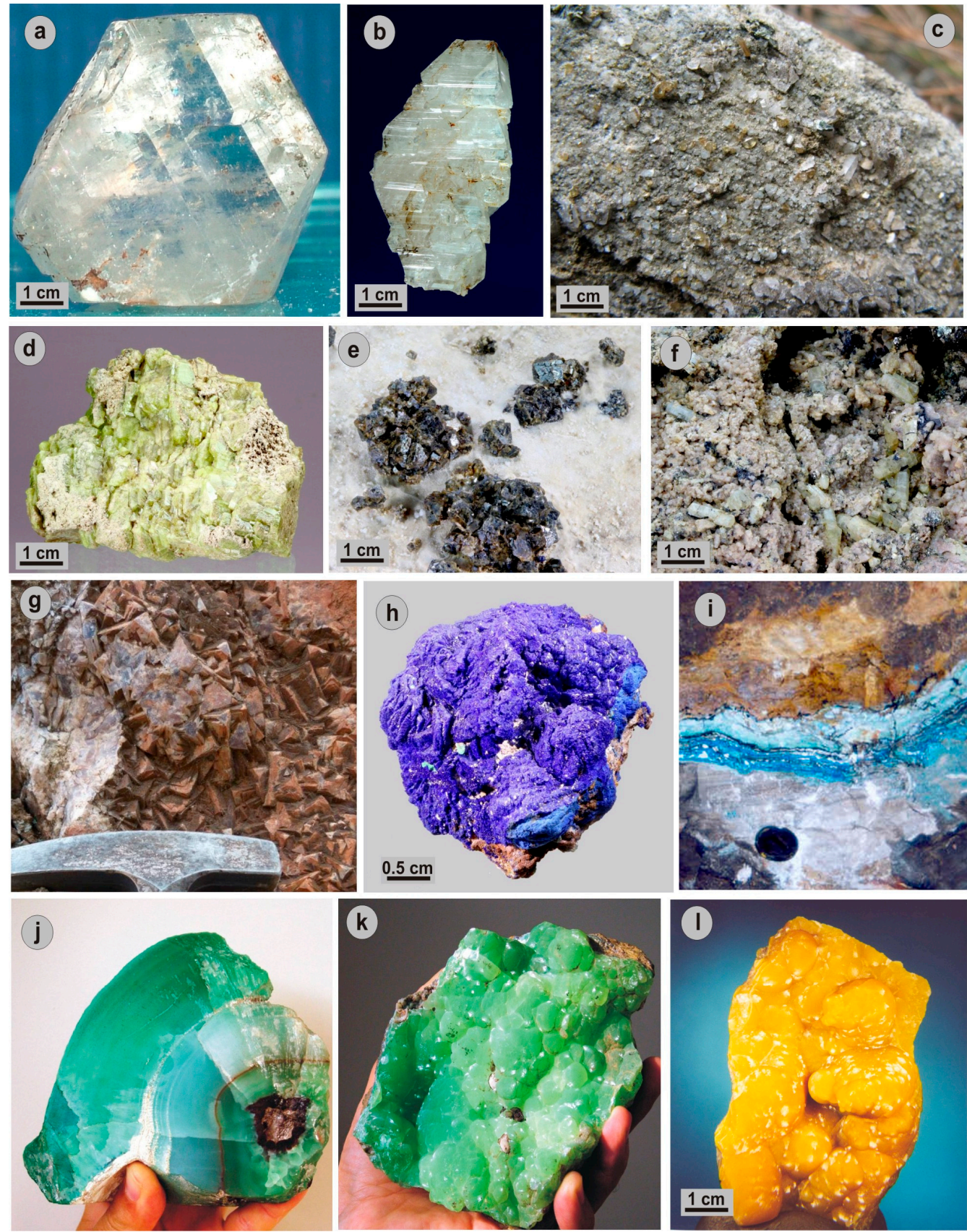

Figure 12. Field and hand specimens photographs demonstrating occurrences/crystals of various gemstones from Greece: (a,b) albite from Krieza, Evia Island; (c) titanite and quartz from Trikorfo, Thassos Island; (d) vesuvianite from the Maronia skarn; (e) spinel in marble from Gorgona, Xanthi; (f) apatite and K-feldspar from potassically-altered monzonite, Fakos, Limnos Island; (g) purple fluorite coated with iron oxides, Ampelos, Samos Island; (h) azurite, Kamariza, Lavrion deposit; (i) blue smithsonite within marble at the interface with Fe-oxides, Kamariza, Lavrion; (j-1) colored varieties of smithsonite, Kamariza, Lavrion deposit; Photographs $12 \mathrm{~b}, \mathrm{~d}, \mathrm{e}, \mathrm{f}, \mathrm{h}$ are courtesy of Berthold Ottens.

\subsection{Spinel}

Spinel at Gorgona, Xanthi occurs either as isolated crystals or as rims around corundum. The color of spinel ranges from blue to green and brown (Figure 12e). Transparent blue-colored octahedral spinel crystals up to $1 \mathrm{~cm}$ occur at Maronia in association with phlogopite and grossular. 


\subsection{Tourmaline}

Tourmaline is abundant in quartz veins and lenses at Trikorfo and Thymonia/Thassos, in black crystals (schorl) reaching up to $10 \mathrm{~cm}$. However this material is not suitable as a gemstone. Similar crystals occur in pegmatites near Nevrokopi-Drama and at Naxos Island. Nickel-bearing brown tourmaline (dravite) accompanies corundum in the marbles at Gorgona, Xanthi and contains up to $4.4 \mathrm{wt}$. \% $\mathrm{NiO}$, much higher than the Ni content reported in tourmaline from Samos and nickeloan tourmaline from the Berezovskoe gold deposit by Henry and Dutrow [67] and Baksheev and Kudryavtseva [68] respectively. Crystals are generally small (up to $1 \mathrm{~cm}$ ) but are locally transparent and of gem-quality.

\subsection{Apatite, Fluorite, Azurite, Turquoise}

Transparent apatite in well-shaped crystals, $1 \mathrm{~cm}$ long, accompany phlogopite and orthoclase in the potassic alteration zone at Fakos, Limnos Island (Figure 12f). The carbonate-replacement deposits at Lavrion and Serifos are well-known for large fluorite (up to $20 \mathrm{~cm}$ ) crystals with colors varying from blue to purple and green. Gem-quality fluorite is also found in volcanic rocks in Samos and Lesvos Islands, where monominerallic fluorite veins cross-cut epithermally altered silicified zones and propylitically altered lavas. The veins are banded and the voids are filled with deep violet and green colored crystals up to $5 \mathrm{~cm}$ respectively (Figure 12g). Azurite associated with malachite is widespread in the Lavrion deposit in crystals up to $4 \mathrm{~cm}$ as well as in large massive aggregates suitable for cabochon cutting (Figure 12h). Turquoise in gem-quality occurs in the oxidation zone of the Vathi porphyry $\mathrm{Cu}-\mathrm{Au}$ deposit, Kilkis area [69].

\subsection{Smithsonite}

The Lavrion smithsonite occurs in many different forms and colorations (Figure 12i-1). Samples have pale blue or green and yellow colors due to both solid solutions and impurities of other minerals $[11,70]$. The Lavrion smithsonites were intensively exploited during the last one hundred years with a total production of about 1.2 Mt [71]. They occur in cavities in the marbles where they form colorful botryoidal or stalactitic aggregates and/or monominerallic bodies as cavity fillings. The microanalyses suggest that the total content of minor and trace elements in smithsonite is relatively low. The determined elements are $\mathrm{Ca}, \mathrm{Mg}, \mathrm{Fe}, \mathrm{Mn}, \mathrm{Cu}$ and $\mathrm{Cd}$ (Table 4).

Table 4. Fluctuation of trace element content (wt. \%) of selected smithsonite samples from Lavrion (modified after Katerinopoulos et al. [11]).

\begin{tabular}{ccccccccc}
\hline Color & Ca & Mg & Fe & Mn & Cu & Cd & Pb & $\begin{array}{c}\text { Visible } \\
\text { Inclusions }\end{array}$ \\
\hline Yellowish white & $0.1-1.3$ & bd & $0.2-0.8$ & $0-0.2$ & bd & bd & $0.6-1.6$ & - \\
Yellowish grey & $1.1-1.8$ & bd & $0.4-0.9$ & $0-0.2$ & bd & bd & bd & - \\
Light yellow & $0.3-1.5$ & bd & $0.8-1.9$ & $0-0.2$ & bd & bd & bd & - \\
Yellowish brown & $0.2-1.5$ & $0.3-1.8$ & $0.3-5.8$ & $0.3-0.5$ & bd & bd & bd & Chalcophanite \\
Yellowish green & $0.8-1.4$ & bd & 0.4 & $0.3-0.5$ & bd & 0.2 & $0-0.7$ & Greenockite \\
Greenish yellow & 0.3 & bd & bd & bd & bd & 1.1 & 2.3 & Greenockite \\
Light blue & $0.3-1.2$ & bd & bd & bd & $0.3-2.6$ & $0.3-0.7$ & bd & - \\
Bluish white & $0.6-0.9$ & bd & bd & bd & $1.1-2.8$ & bd & bd & - \\
Light green & $0.5-0.7$ & bd & bd & 0.3 & $0.9-3.0$ & bd & bd & - \\
Green & $0.2-0.5$ & bd & bd & $0.2-0.3$ & $1.3-2.4$ & bd & bd & - \\
\hline
\end{tabular}

As $\mathrm{Cd}^{2+}$ is colorless, the yellow ("turkey fat") color of some smithsonites proved to be related only to the presence of greenockite inclusions. Indeed, some samples containing $\mathrm{Cd}$ up to $0.7 \mathrm{wt}$. \% but no greenockite inclusions have colors other than yellow. The absence of $\mathrm{Cu}$-rich impurities in blue and green smithsonite and the relatively high amount of $\mathrm{Cu}$ indicate that there is a limited solid solution between $\mathrm{ZnCO}_{3}$ and the hypothetical $\mathrm{CuCO}_{3}$ molecule (up to $3.0 \mathrm{wt} . \% \mathrm{Cu}$ or $6.3 \mathrm{~mol} \% \mathrm{CuCO}_{3}$ ) (see also Boni et al. [72]; Frisch et al. [73]). This is in accordance to the findings of Samouchos et al. [74] who 
suggested that the blue color in Lavrion smithsonite is due to $\mathrm{Cu}$ substituting for Zn in the structure. Iron substitution of zinc is limited (up to $1.9 \mathrm{wt}$. \% Fe, except for one sample) and turns the color of smithsonite to a pale yellow. Orange and brown colors are related to impurities of $\mathrm{Mn}-\mathrm{Fe}-\mathrm{Pb}$ oxides and hydroxides. The role of manganese is unknown as its content is very low and the influence on the color is weak.

\section{Discussion}

Figure 13 represents a hypothetical schematic model, where gemstone occurrences in Greece are related to the various geological environments (regional metamorphic-metasomatic, alpine-type fissures, plutonic-subvolcanic intrusions and pegmatites, zones of contact metamorphism and peripheral volcanic rocks). The hypothetical depths are speculated on the basis of geological criteria. A Late Cretaceous ( $81.6 \pm 3.5 \mathrm{Ma}$ ) eclogite-facies metamorphism in the Eastern Rhodopes, confirm previous data that multiple subduction events took place between $\sim 200$ and $\sim 40 \mathrm{Ma}$ along this section of the southern European plate boundary [75]. In the Cyclades, following an initial compressional phase of the Alpine Orogeny related to eclogite-facies metamorphism of the rocks at 55-49 Ma [45,76], subsequent exhumation of high-P rocks was accompanied by a regional Barrovian-type metamorphism that locally reached partial melting conditions $[77,78]$. The onset of post-orogenic extensional deformation in the different tectono-metamorphic terranes occurred at $42 \mathrm{Ma}$ for the Rhodope Massif and $\sim 35 \mathrm{Ma}$ for the Cyclades [23]. These early compressional and later syn-orogenic and post-orogenic extensional events were responsible for the formation of most gemstones found in both regional metamorphic rocks, as well as in late alpine-fissures in Greece. For ruby and jadeite the term "Plate tectonic gemstones" has been proposed by Stern et al. [5], since they generally form as a result of the plate tectonic processes subduction and collision.

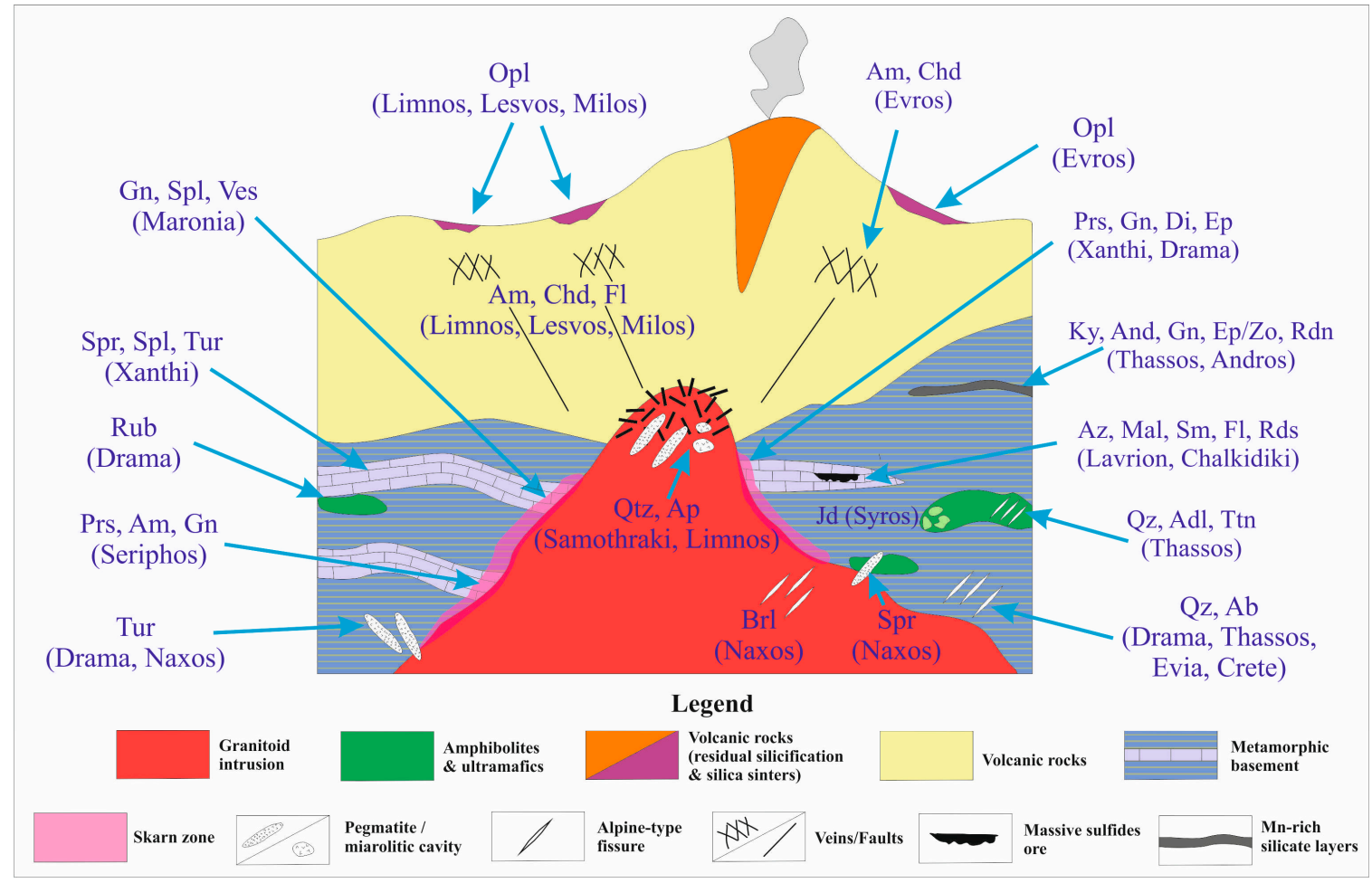

Figure 13. Hypothetical model presenting the various environments related to crystallization of gemstones in Greece. Abbreviations: Ab: Albite, Adl: Adularia; Am: Amethyst, And: Andalusite; Ap: Apatite; Az: Azurite; Brl: Beryl, Chd: Chalcedony, Di: Diopside, Epid: Epidote, Fl: Fluorite, Gn: Garnet, Jd: Jadeite; Ky: Kyanite; Prs: Prase; Rdn: Rhodonite; Rds: Rhodochrosite; Sm: Smithsonite; Spr: Sapphire, Spl: Spinel; Ttn: Titanite; Tur: Tourmaline, Ves: Vesuvianite. 
Formation of the jadeitite bodies at Syros Island involved fluid interaction in and around serpentinized peridotite, derived from subduction zone devolatilization [27]. Rodingitization of doleritic and gabbroic dykes in the Rhodope massif and the Pelagonian zone is associated with metasomatic alteration processes, which resulted in the formation of garnet and vesuvianite [79]. According to Koutsovitis et al. [79], rodingitization took place during the exhumation of the mafic-ultramafic mantle wedge rocks within a serpentinitic subduction channel.

Gem corundums in Greece cover a variety of geological environments. The pargasite-schist hosted ruby deposit at Paranesti/Drama area and marble-hosted pink to blue sapphires in Xanthi area occur along the UHP-HP Nestos suture zone and are classified as metamorphic s.s hosted in mafics/ultramafics and marbles respectively [18]. At the Trikorfo area (Thassos Island, Rhodope massif, Northern Greece), which represents a unique mineralogical locality with Mn-bearing minerals such as kyanite, andalusite, garnet and epidote, localized metasomatic reactions occurred during the exhumation of the HP unit locally containing layers enriched in Mn with a strong local $f \mathrm{O}_{2}$ buffering [19]. Metasomatic reactions first occurred under ductile conditions in an extensive context close to the kyanite-andalusite stability curve and continued until purely brittle conditions as indicated by the presence of late alpine-type veins cross-cutting the metamorphic foliation [19].

Based on the existing data, it can be proposed that the formation of the studied alpine-type fissures in Greece and their mineralogy are closely related to the extensional tectonics accompanying the exhumation of the metamorphic rocks. This was a favored environment for the crystallization of gem-quality quartz and albite. A decrease in pressure and temperature around the fissures during exhumation caused oversaturation in $\mathrm{SiO}_{2}$ and precipitation of quartz and other mineral constituents in the fissures. Leaching of chemical components from the host rocks after their interaction with the hydrothermal fluids could also explain fluid enrichment and deposition of alpine-type minerals in the fissures studied. The blue sapphires hosted in metabauxites from southern Naxos and Ikaria, fill open-spaces in fissures cross-cutting the metamorphic foliation. They display atypical magmatic signatures indicating a hydrothermal origin and were formed during late extensional conditions.

The development of magmatic-hydrothermal and epithermal systems during the Tertiary, is closely associated with crystallization of a large variety of gemstones. Several gemstones related to the Tertiary magmatic activity are developed within and around the magmatic centres in W. Thrace (Kimmeria, Kassiteres-Sapes, Maronia-Perama, Soufli-Dadia-Levkimi, Drama, Samothraki), Limnos, Lesvos, Serifos and Milos Islands. Initial deep mineralization occurred where plutonic bodies intruded within the basement rocks. Residual fluids, enriched in volatiles, resulted in the emplacement of pegmatitic bodies and to crystallization of beryl (aquamarine) $[80,81]$ and sapphires (in desilicated pegmatites intruding ultramafic rocks) at Naxos Island. Metasomatic processes caused by the release of magmatic-hydrothermal fluids from the intrusive rocks, led to the deposition of various gemstones in the intrusive bodies as well as in the surrounding rocks.

The mineralization in skarns started with the deposition of anhydrous minerals, some of them of gem-quality such as garnets, spinel, titanite and diopside, and ended in the deposition of gem-varieties of quartz, epidote, and vesuvianite in a retrograde stage and under temperature decrease and meteoric water incursion. Contemporaneously, magmatic-hydrothermal fluids circulating within the granitoids were responsible for the deposition of quartz within miarolitic cavities and within quartz veins associated with feldspar, and gemmy apatite.

Later, the systems shifted from a magmatic-hydrothermal dominated stage to a geothermal one, due to the increasing incursion of meteoric waters. Changes in the physico-chemical conditions of the ascending geothermal fluids were the major factors controlling the mineral deposition of the silica varieties (quartz, amethyst, chalcedony and opal) in this geothermal-epithermal environment. Opalized horizons in Thrace and Limnos could represent silica sinter deposition from alkali or neutral geothermal fluids [82]. Amethyst, indicative of oxidizing conditions [83], was probably deposited as a result of mixing of the ascending hydrothermal fluids with meteoric and/or seawater. 
Finally, gem-quality smithsonite in the supergene oxidation zone of the Lavrion/Attika carbonate-replacement deposit, was formed as a result of reactivity of carbonate minerals with acidic, zinc-rich solutions, derived from the destruction of sphalerite $[11,84,85]$. According to the above authors, the neutralization of the acidic solutions deep in the marbles produces enough $\mathrm{CO}_{2}$ to make smithsonite the stable phase at $\mathrm{pH}$ values near neutral.

All Greek corundum, especially the vivid-colored varieties, are translucent to opaque, suitable for cabochons (Figure 14). Greek corundums are characterized by a wide color variation ranging from deep red, pink, purple, and blue to colorless, with crystal sizes of up to $5 \mathrm{~cm}$, homogeneity of the color hues and transparency and should be further examined for their suitability as potential faceted gemstones. Similarly, at Trikorfo/Thassos crystals of kyanite, green andalusite, garnet (grossular and spessartine) and red zoisite-clinozoisite are large (up to several $\mathrm{cm}$ ), show vivid colors, and are suitable for cabochons.

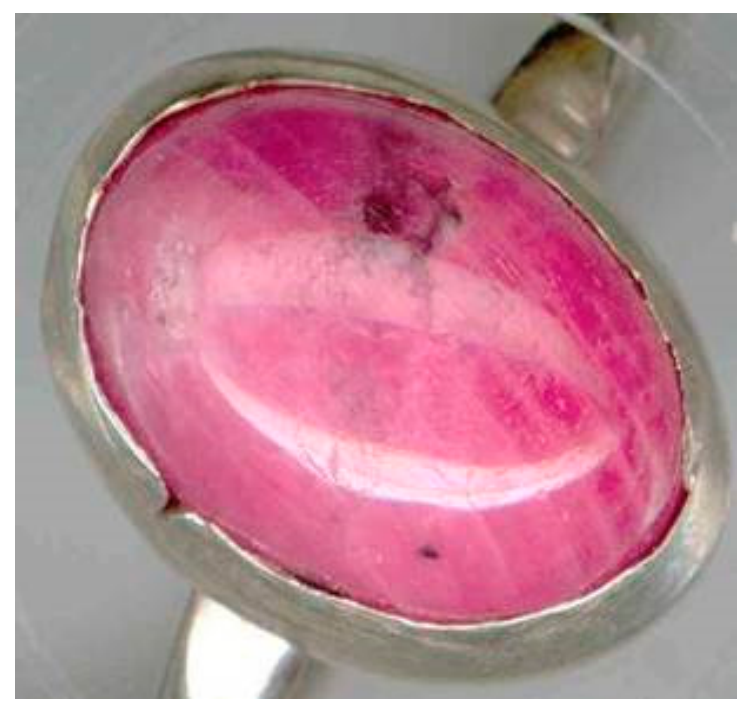

Figure 14. Cabochon quality ruby from Paranesti Drama. Photograph courtesy of V. Melfos.

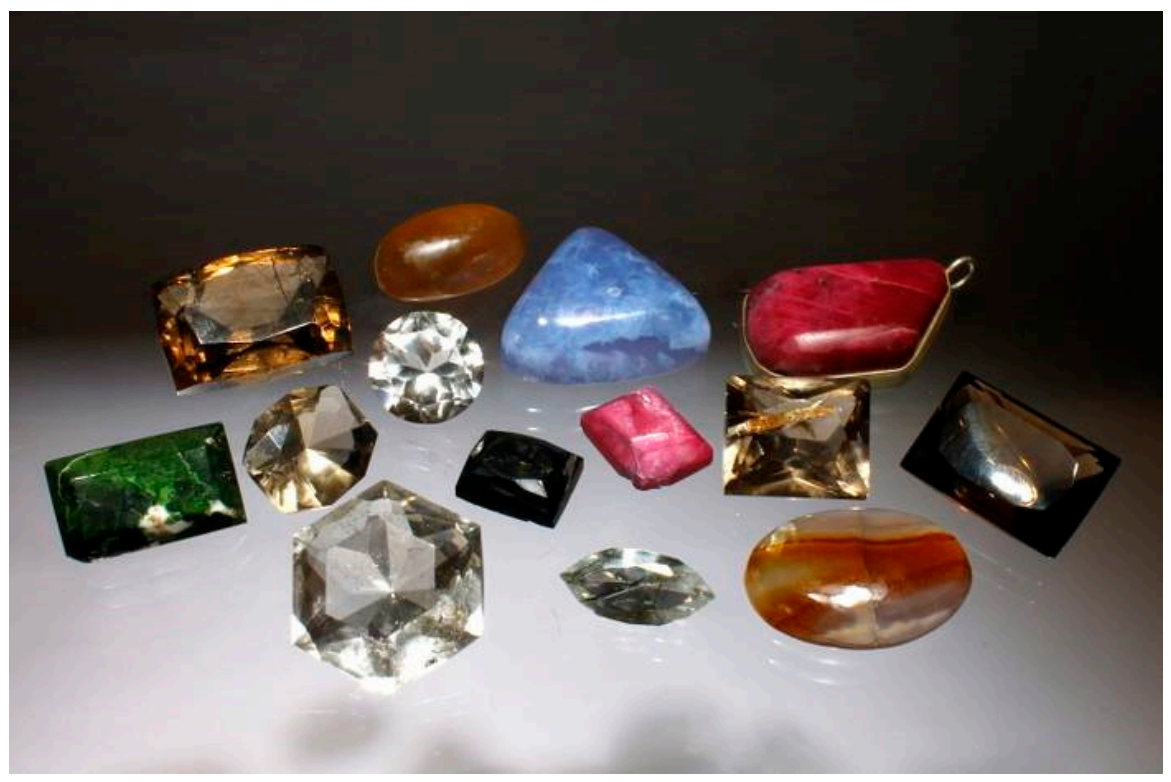

Figure 15. Various faceted and cabochon gemstones from Greece. Green Mn-andalusite from Thassos $(2.2 \mathrm{~cm}$ length) in the left, dark green epidote from Kimmeria $(1.3 \mathrm{~cm})$ in the center, ruby from Paranesti $(4 \mathrm{~cm})$ in the right of the photograph. The rest are silica varieties. Photo courtesy of Anastasios Tsinidis. 
As such, the Trikorfo locality can be regarded as a promising area for the exploration of transparent, facetable gemstones. Their genesis due to metasomatic reactions also underlines the important role of metasomatism for gemstone formation in general, as previously noted in the literature $[2,19]$. According to Tarantola et al. [19], Thassos Island (Rhodope, Greece) can now be classified as the second locality worldwide where Mn-rich orange kyanite is reported, after that of Loliondo (Tanzania) deposit. Finally, silica varieties provide excellent facetable material or cabochons (Figure 15). Future exploration in addition to detailed studies of trace and minor element chemistry using LA-ICP-MS analysis and gemological evaluations are required in order to establish the potential for economic exploitation and to consider them as marketable gems.

\section{Conclusions}

In the accretionary Hellenides Orogen, gemstones occur in various rock types of mainly four tectonometamorphic units, the Rhodope- and the Attico-Cycladic massifs, the Pelagonian zone, and the Phyllites-Quartzites of Crete Island. In crystalline rocks, two groups of gemstones are distinguished, those formed during regional metamorphism and those associated with late alpine-type fissures. The first group includes Mn-bearing silicates (Mn-andalusite, spessartine, Mn-grossular, Mn-clinozoisite, Mn-zoisite and orange-colored Fe-Mn-kyanite) hosted in Carboniferous ortho- and paragneisses in both Thassos and Paros Islands (Rhodope- and Attico-Cycladic massifs respectively), as well as gem corundums in Xanthi-Drama areas/Rhodope massif and Naxos-Ikaria Islands (Attico-Cycladic massif). In the Xanthi-Drama area, corundum mineralization (sapphires and rubies) is distributed within marbles and eclogitic amphibolites oriented parallel to the (UHP-HP) Nestos suture zone. In the Attico-Cycladic massif, blue sapphires are found within marble-hosted metabauxites (Ikaria and Naxos Island). Alpine-type fissures in Greece contain gem-quality quartz (green quartz, amethyst, smoky and colorless quartz), albite and titanite. Host lithologies are ortho- and paragneisses and metabasites in the Rhodope- (Drama, Thassos Island) and the Attico-Cycladic (Pentelikon Mt, Evia, Ios Islands) Massifs, and metaquartzites (Crete Island). Metamorphic/metasomatic processes within a subduction channel, resulted in the formation of the jadeitite bodies at Syros Island and of garnet and vesuvianite in rodingite bodies at the Rhodope massif and the Pelagonian zone.

The Tertiary magmatic-hydrothermal environments in Greece (granitoids, pegmatites, skarns and carbonate-replacement deposits, and volcanic rocks) may also provide facet-quality material of several species (beryl, sapphire, garnet, vesuvianite, diopside, epidote, fluorite, rhodochrosite, quartz varieties and silica microcrystalline species). The Naxos pegmatites are prospective for aquamarine and blue, purple to pink colored sapphires. Miarolitic cavities and quartz veins cross-cutting granitoids (Samothraki Island, Maronia and, Kimmeria) contain gem-quality colorless and smoky quartz. The endo- and exoskarns of Kimmeria, Kresti and Maronia (Rhodope massif), Serifos Island (Attico-Cycladic massif) and Kos Island, host facetable grossular-andradite garnets, vesuvianite, epidote, as well as prase and amethyst crystals. Rhodochrosite and fluorite occur in the carbonate-replacement deposits of Olympias/Chalkidiki and Lavrion/Attika respectively. Gemstones associated with hydrothermally-altered volcanic rocks include amethyst, chalcedony, opal, fossilized wood and fluorite in Sapes, Soufli areas (Rhodope massif), Lesvos, Limnos and Samos Islands (northeastern and central Aegean volcanic arc) and Milos Island (Attico-Cycladic massif-south Aegean volcanic arc). Finally, the supergene oxidation of the Lavrion/Attika carbonate-replacement deposit contains gem-quality smithsonite in several colorations. Future work aims towards a gemological evaluation of the Greek gemstones and finally estimating the potential for their possible exploitation.

Author Contributions: P.V. and C.M. collected the studied samples. P.V. assisted by C.M., I.G., G.G., A.T., V.M., S.K., A.K., and A.M., evaluated the mineralogical and oxygen isotopic data. P.V. wrote the manuscript.

Funding: This research received no external funding.

Acknowledgments: Authors would like to thank Stefanie Heidrich for her kind help on microanalyses in the Institute of Mineralogy and Petrography, University of Hamburg and Berthold Ottens and Anastasios Tsinidis for kindly providing photographs of Greek mineral specimens and gemstones respectively. 
Conflicts of Interest: The authors declare no conflict of interest.

\section{References}

1. Fritsch, E.; Rondeau, B. Gemology: The Developing Science of Gems. Elements 2009, 5, 147-152. [CrossRef]

2. Groat, L.A.; Laurs, B.M. Gem Formation, Production, and Exploration: Why Gem Deposits Are Rare and What is Being Done to Find Them. Elements 2009, 5, 153-158. [CrossRef]

3. Groat, L.A. (Ed.) Geology of Gem Deposits; Mineralogical Association of Canada Short Course 37: Quebec City, QC, Canada, 2007; 276p.

4. Groat, L.A. Gemstones. Am. Sci. 2012, 100, 128-137.

5. Stern, R.J.; Tsujimori, T.; Harlow, G.; Groat, L.A. Plate tectonic gemstones. Geology 2013, 41, $723-726$. [CrossRef]

6. Kievlenko, E.Y. Geology of Gems; Soregaroli, A., Ed.; Ocean Pictures Ltd.: Littleton, CO, USA, 2003; 432p.

7. Tsirambides, A.E. The Minerals Wealth of Greece; Giachoudi Pulb.: Thessaloniki, Greece, 2005; 391p.

8. Andronopoulos, V.; Tsoutrelis, C. Investigation of a Red Corundum Occurrence in Xanthi, Greece; Unpublished Report; Greek Geol. Survey: Athens, Greece, 1964; 8p.

9. Papastamatiou, I. The Emery of Naxos. Geol. Geoph. Res. 1951, 1, 37-68.

10. Paraskevopoulos, G. Die Entstehung der Manganlagerstaetten auf der Insel Paros, Griechenland. N. Jb. Min. Abh. 1958, 90, 367-380.

11. Katerinopoulos, A.; Solomos, Ch.; Voudouris, P. Lavrion smithsonites: A mineralogical and mineral chemical study of their coloration. In Mineral Deposit Research: Meeting the Global Challenge; Mao, J., Bierlein, F.P., Eds.; Springer: Berlin, Germany, 2005; pp. 983-986.

12. Gauthier, G.; Albandakis, N. Minerals from the Serifos skarn, Greece. Mineral. Rec. 1991, 22, 303-308.

13. Voudouris, P.; Katerinopoulos, A. New occurences of mineral megacrysts in tertiary magmatic-hydrothermal and epithermal environments in Greece. Doc. Nat. 2004, 151, 1-21.

14. Voudouris, P.; Katerinopoulos, A.; Melfos, V. Alpine-type fissure minerals in Greece. Doc. Nat. 2004, 151, $23-45$.

15. Voudouris, P.; Melfos, V.; Katerinopoulos, A. Precious stones in Greece: Mineralogy and geological environment of formation. In Proceedings of the Understanding the Genesis of Ore Deposits to Meet the Demand of the 21st Century, Moscow, Russia, 21-24 August 2006; p. 6.

16. Voudouris, P.; Graham, I.; Melfos, V.; Sutherland, L.; Zaw, K. Gemstones in Greece: Mineralogy and crystallizing environment. In Proceedings of the 34th IGC conference, Brisbane, Australia, 5-10 August 2012.

17. Ottens, B.; Voudouris, P. Griechenland: Mineralien-Fundorte-Lagerstätten; ChristianWeise Verlag: Munchen, Germany, 2018; 480p.

18. Voudouris, P.; Mavrogonatos, C.; Graham, I.; Giuliani, G.; Melfos, V.; Karampelas, S.; Karantoni, V.; Wang, K.; Tarantola, A.; Zaw, K.; et al. Gem Corundum Deposits of Greece: Geology, Mineralogy and Genesis. Minerals 2019, 9, 49. [CrossRef]

19. Tarantola, A.; Voudouris, P.; Eglinger, A.; Scheffer, C.; Trebus, K.; Bitte, M.; Rondeau, B.; Mavrogonatos, C.; Graham, I.; Etienne, M.; et al. Metamorphic and Metasomatic Kyanite-Bearing Mineral Assemblages of Thassos Island (Rhodope, Greece). Minerals 2019, 9, 252. [CrossRef]

20. Pouchou, J.-L.; Pichoir, F. Quantitative Analysis of Homogeneous or Stratified Microvolumes Applying the Model "PAP". In Electron Probe Quantitation; Heinrich, K.F.J., Newbury, D.E., Eds.; Springer: Boston, MA, USA, 1991; pp. 31-75. ISBN 978-1-4899-2617-3.

21. Mattey, D.P. LaserPrep: An Automatic Laser-Fluorination System for Micromass 'Optima' or 'Prism' Mass Spectrometers. Micromass Appl. Note 1997, 207, 8.

22. Jolivet, L.; Brun, J.P. Cenozoic geodynamic evolution of the Aegean region. Int. J. Earth. Sci. 2010, 99, $109-138$. [CrossRef]

23. Jolivet, L.; Faccenna, C.; Huet, B.; Labrousse, L.; Le Pourhiet, L.; Lacombe, O.; Lecomte, E.; Burov, E.; Denèle, Y.; Brun, J.-P.; et al. Aegean tectonics: Strain localization, slab tearing and trench retreat. Tectonophysics 2013, 597, 1-33. [CrossRef]

24. Ring, U.; Glodny, J.; Thomson, S. The Hellenic subduction system: High-pressure metamorphism, exhumation, normal faulting and large-scale extension. Earth Plan. Sci. 2010, 38, 45-76. [CrossRef] 
25. Brun, J.-P.; Sokoutis, D. Kinematics of the Southern Rhodope Core Complex (North Greece). Int. J. Earth Sci. 2007, 96, 1079-1099. [CrossRef]

26. Pe-Piper, G.; Piper, D.J.W. The igneous rocks of Greece. The anatomy of an orogen. In Beiträge der regionalen Geologie der Erde 30; Stuttgart: Berlin, Germany, 2002; 573p.

27. Harlow, G.E.; Sorensen, S.S.; Sisson, V.B. Jade. In The Geology of Gem Deposits; Groat, L.A., Ed.; Mineralogical Association of Canada Short Course Series: Quebec City, QC, Canada, 2007; Volume 37, pp. 207-254.

28. Wang, K.K.; Graham, I.T.; Lay, A.; Harris, S.J.; Cohen, D.R.; Voudouris, P.; Belousova, E.; Giuliani, G.; Fallick, A.E.; Greig, A. The Origin of A New Pargasite-Schist Hosted Ruby Deposit From Paranesti, Northern Greece. Can. Mineral. 2017, 55, 535-560. [CrossRef]

29. Wang, K.K.; Graham, I.T.; Martin, L.; Voudouris, P.; Giuliani, G.; Lay, A.; Harris, S.J.; Fallick, A. Fingerprinting Paranesti Rubies through Oxygen Isotopes. Minerals 2019, 9, 91. [CrossRef]

30. Papanikolaou, D. Contribution to the geology of the Aegean Sea: The Island of Andros. Ann. Geol Pays Hell. 1978, 29, 477-553.

31. Stalder, H.A. Petrographische und mineralogische Untersuchungen im Grimselgebiet (Mittleres Aarmassiv). Schweiz Miner. Petr. Mitt. 1964, 44, 187-398.

32. Mullis, J. Growth conditions of quartz crystals from Val d'Illiez (Valais, Switzerland). Schweiz Miner. Petr. Mitt. 1975, 55/3, 419-430.

33. Niedermayer, G. Alpine Kluefte. Min. Welt 1993, 6, 57-59.

34. Ottens, B.; Tsinidis, T.; Voudouris, P. Amethyst and smoky quartz: Scepter crystals from Kato Nevrokopi, Greece. Lapis 2016, 41, 10-21. (In German)

35. Voudouris, P.; Melfos, V.; Mavrogonatos, C.; Tarantola, A.; Götze, J.; Alfieris, D.; Maneta, V.; Psimis, I. Amethyst occurrences in Tertiary volcanic rocks of Greece: Mineralogical, fluid inclusion and oxygen isotope constraints on their genesis. Minerals 2018, 8, 324. [CrossRef]

36. Liati, A. Corundum-and zoisite-bearing marbles in the Rhodope Zone, Xanthi area (N. Greece): Estimation of the fluid phase composition. Mineral. Petrol. 1988, 38, 53-60. [CrossRef]

37. Voudouris, P.; Graham, I.; Melfos, V.; Zaw, K.; Lin, S.; Giuliani, G.; Fallick, A.; Ionescu, M. Gem corundum deposits of Greece: Diversity, chemistry and origins. In Proceedings of the 13th Quadrennial IAGOD Symposium, Adelaide, Australia, 6-9 April 2010; Volume 69, pp. 429-430.

38. Graham, I.; Voudouris, P.; Melfos, V.; Zaw, K.; Meffre, S.; Sutherland, F.; Giuliani, G.; Fallick, A. Gem corundum deposits of Greece: A spectrum of compositions and origins. In Proceedings of the 34th IGC Conference, Brisbane, Australia, 5-10 August 2012.

39. Feenstra, A.; Wunder, B. Dehydration of diasporite to corundite in nature and experiment. Geology 2002, 30, 119-122. [CrossRef]

40. Sutherland, F.L.; Zaw, K.; Meffre, S.; Giuliani, G.; Fallick, A.E.; Graham, I.T.; Webb, G.B. Gem corundum megacrysts from East Australia basalt fields: Trace elements, $\mathrm{O}$ isotopes and origins. Aust. J. Earth Sci. 2009, 56, 1003-1020. [CrossRef]

41. Harris, S.J.; Graham, I.T.; Lay, A.; Powell, W.; Belousova, E.; Zappetini, E. Trace element geochemistry and metasomatic origin of alluvial sapphires from the Orosmayo region, Jujuy Province, Northwest Argentina. Can. Mineral. 2017, 55, 595-617. [CrossRef]

42. Peucat, J.J.; Ruffault, P.; Fritsch, E.; Bouhnik-Le Coz, M.; Simonet, C.; Lasnier, B. Ga/Mg ratio as a new geochemical tool to differentiate magmatic from metamorphic blue sapphires. Lithos 2007, 98, 261-274. [CrossRef]

43. Giuliani, G.; Caumon, G.; Rakotosamizanany, S.; Ohnenstetter, D.; Rakototondrazafy, M. Classification chimique des corindons par analyse factorielle discriminante: Application a la typologie des gisements de rubis et saphirs. Chapter mineralogy, physical properties and geochemistry. Rev. Gemmol. 2014, 188, 14-22.

44. Tsujimori, T.; Harlow, G.E. Petrogenic relationships between jadeitite and associated high-pressure and low-temperature metamorphic rocks in worldwide jadeitite localities: A review. Eur. J. Min. 2012, 24, 371-390. [CrossRef]

45. Bröcker, M.; Endrers, M. U-Pb zircon geochronology of unusual eclogite-facies rocks from Syros and Tinos (Cyclades, Greece). Geol. Mag. 1999, 136, 111-118.

46. Higgins, M.D. Neolithic jadeite and eclogite axes from Greece: A possible material source on the Island of Syros, Greece. In GAC-MAC-CSPG-CSSS; Hallifax: Nova Scotia, Canada, 2005; Volume 30. 
47. Voudouris, P.; Graham, I.; Mavrogonatos, K.; Su, S.; Papavasiliou, K.; Farmaki, M.-V.; Panagiotidis, P. Mn-andalusite, spessartine, Mn-grossular, piemontite and Mn-zoisite/clinozoisite from Trikorfo, Thassos Island, Greece. Bull. Geol. Soc. Greece 2016, 50, 2068-2078. [CrossRef]

48. Fitros, M.; Tombros, S.F.; Simos, X.C.; Kokkalas, S.; Hatzipanagiotou, K. Formation of Mn-skarn Ores at Thapsana Mines, Paros Island, Attico-Cycladic Metallogenetic Massif, Greece. In Proceedings of the the 1st Int. Electronic Conference on Mineral Science, 16-31 July 2018; Sciforum, MDPI AG: Basel, Switzerland.

49. Voudouris, P.; Katerinopoulos, A.; Magganas, A. Mineralogical geotopes in Greece: Preservation and promotion of museum specimens of minerals and gemstones. Sofia Initiative "Mineral diversity preservation". In Proceedings of the IX International Symposium on Mineral Diversity Research and Reservation, Sofia, Bulgaria, 16-18 October 2017; pp. 149-159.

50. Maneta, V.; Voudouris, P. Quartz megacrysts in Greece: Mineralogy and environment of formation. Bull. Geol. Soc. Greece 2010, 43, 685-696. [CrossRef]

51. Voudouris, P.; Constantinidou, S.; Kati, M.; Mavrogonatos, C.; Kanellopoulos, C.; Volioti, E. Genesis of alpinotype fissure minerals from Thassos Island, Northern Greece-Mineralogy, mineral chemistry and crystallizing environment. Bull. Geol. Soc. Greece 2013, 47, 468-476. [CrossRef]

52. Klemme, S.; Berndt, J.; Mavrogonatos, C.; Flemetakis, S.; Baziotis, I.; Voudouris, P.; Xydous, S. On the color and genesis of prase (green quartz) and Amethyst from the Island of Serifos, Cyclades, Greece. Minerals 2018, 8, 487. [CrossRef]

53. Ottens, B.; Voudouris, P. Minerals and gold ores: The mining district of Chalkidiki, Greece. Lapis 2007, 42, 32-58. (In German)

54. Taylor, H.P., Jr. Oxygen and hydrogen isotope relationships in hydrothermal mineral deposits. In Geochemistry of Hydrothermal Ore Deposits, 2nd ed.; Barnes, H.L., Ed.; Wiley: New York, NY, USA, 1979; pp. 236-318.

55. Giggenbach, W.F. The origin and evolution of fluids in magmatic-hydrothermal systems. In Geochemistry of Hydrothermal Ore Deposits, 3rd ed.; Barnes, H.L., Ed.; Wiley: New York, NY, USA, 1997; pp. 737-796.

56. Sharp, Z.D.; Gibbons, J.A.; Maltsev, O.; Atudorei, V.; Pack, A.; Sengupta, S.; Shock, E.L.; Knauth, L.P. A calibration of the triple oxygen isotope fractionation in the $\mathrm{SiO}_{2}-\mathrm{H}_{2} \mathrm{O}$ system and applications to natural samples. Geochim. Cosmochim. Acta 2016, 186, 105-119. [CrossRef]

57. Melfos, V.; Voudouris, P. Fluid inclusions and O-isotopes of an amethyst and smoky quartz occurrence in Kato Nevrokopi, Rhodope massif, Northern Greece. In Proceedings of the 11th International Conference on Experimental Mineralogy Petrology Geochemistry, Bristol, UK, 11-13 September 2006.

58. Bitte, M.; Tarantola, A.; Scheffer, C.; Voudouris, P.; Valero, M. Fluid Inclusion Characterization of Alpine-Type Quartz Tension Gashes of Thassos Island (Rhodope Massif, Greece); European Current Research on Fluid and Melt Inclusions (ECROFI): Nancy, France, 2019.

59. Tarantola, A.; Scheffer, C.; Voudouris, P.; Vanderhaeghe, O.; Rakotomanga, S.; Rigaudier, T. Metamorphic and Basin Fluids Trapped in Evia Island Alpine Quartz Crystals during Exhumation of the Attic-Cycladic Metamorphic Complex (Greece); ECROFI 24: Nancy, France, 2017.

60. Thewalt, U.; Voudouris, P. Jaspis von Sykorachi (Thrakien, Griechenland) und seine Einschlüsse. Miner. Welt 2019, 5, 92-96.

61. Thewalt, U.; Dorfner, G.; Samouchos, M. Chalcedon, Achat und Jaspis vom westlichen Kustenbereich des Golfs von Kalloni, Lesbos, Griechenland. Miner. Welt 2018, 5, 90-96.

62. Kelepertzis, A.E.; Velitzelos, E. Oligocene swamp sediments of Lesvos Island, Greece (Geochemistry and Mineralogy). Facies 1992, 27, 113-118. [CrossRef]

63. Velitzelos, E.; Zouros, N. The Petrified Forest of Lesvos. In Protected Natural Monument, Engineering Geology and the Environment; Marinos, P., Koukis, G., Tsiambaos, G., Stournaras, G., Eds.; Balkema: Rotterdam, The Netherlands, 1997; pp. 3037-3043.

64. Voudouris, P.; Velitzelos, D.; Velitzelos, E.; Thewald, U. Petrified wood occurences in western Thrace and Limnos Island: Mineralogy, geochemistry and depositional environment. Bull. Geol. Soc. Greece 2007, 40, 238-250. [CrossRef]

65. Papp, A. Erläuterungen zur Geologie der Insel Lemnos. Ann. Geol. Pays Hell. 1953, 5, 1-33.

66. Kassoli-Fournaraki, A.; Michailidis, K.; Zanas, I.; Zachos, S. Titanite-rich carbonates from the Therapio area in Thrace, northern Greece: constraints of the mineral assemblage formation. Schw. Mineral. Petr. Mitt. 1995, 75, 387-398. 
67. Henry, D.J.; Dutrow, B.L. Compositional zoning and element partitioning in nickeloan tourmaline from metamorphosed karstbauxite from Samos, Greece. Am. Mineral. 2001, 86, 1130-1142. [CrossRef]

68. Baksheev, I.A.; Kudryavtseva, O.E. Nickeloan tourmaline from the Berezovskoe gold deposit, Middle Urals, Russia. Can. Mineral. 2004, 42, 1065-1078. [CrossRef]

69. Sklavounos, S.; Ericsson, T.; Filippidis, A.; Michailidis, K.; Kougoulis, C. Chemical, X-ray and Mossbauer investigation of a turquoise from the Vathi area volcanic rocks, Macedonia, Greece. Neues Jahrb. Mineral. Mh. 1992, 469-480.

70. Voudouris, P.; Tsolakos, A.; Papanikitas, A.; Solomos, C. Neufunde aus Lavrion. Lapis 2004, 29, 13-15.

71. Marinos, G.; Petrascheck, W.E. Laurium. Geological and geophysical research. Greece Inst. Geol. Subsurf. Res. 1956, 4, 1-247.

72. Boni, M.; Gilg, H.A.; Aversa, G.; Balassone, G. The “Calamine” of Southwest Sardinia: Geology, Mineralogy, and Stable Isotope Geochemistry of Supergene Zn Mineralization. Econ. Geol. 2003, 98, 731-748. [CrossRef]

73. Frisch, P.L.; Lueth, V.W.; Hlava, P.F. The colors of smithsonite: A microchemical investigation. New Mexico. Geology 2002, 24, 132-133.

74. Samouhos, M.; Zavašnik, J.; Rečnik, A.; Godelitsas, A.; Chatzitheodoridis, E.; Sanakis, Y. Spectroscopic and nanoscale characterization of blue-colored smithsonite $\left(\mathrm{ZnCO}_{3}\right)$ from Lavrion historical mines (Greece). Per. Mineral. 2015, 84, 373-388.

75. Miladinova, I.; Froitzheim, N.; Nagel, T.J.; Janák, M.; Georgiev, N.; Fonseca, R.O.C.; Sandmann, S.; Münker, C. Late Cretaceous eclogite in the Eastern Rhodopes (Bulgaria): Evidence for subduction under the Sredna Gora magmatic arc. Int. J. Earth Sci. 2018, 107, 2083-2099. [CrossRef]

76. Laurent, V.; Huet, B.; Labrousse, L.; Jolivet, L.; Monie, P.; Augier, R. Extraneous argon in high-pressure metamorphic rocks: Distribution, origin and transport in the Cycladic Blueschist Unit (Greece). Lithos 2017, 272, 315-335. [CrossRef]

77. Altherr, R.; Kreuzer, H.; Wendt, I.; Lenz, H.; Wagner, G.A.; Keller, J.; Harre, W.; Höhndorf, A. A late Oligocene/early Miocene high temperature belt in the Attic-Cycladic crystalline complex (SE Pelagonian, Greece). Geol. Jahrb. 1982, 23, 97-164.

78. Keay, S.; Lister, G.; Buick, I. The timing of partial melting, Barrovian metamorphism and granite intrusion in the Naxos metamorphic core complex, Cyclades, Aegean Sea, Greece. Tectonophysics 2001, 342, 275-312. [CrossRef]

79. Koutsovitis, P.; Magganas, A.; Pomonis, P.; Ntaflos, T. Subduction-related rodingites from East Othris, Greece: Mineral reactions and physicochemical conditions of formation. Lithos 2013, 172-173, 139-157. [CrossRef]

80. Jansen, J.B.H.; Schuiling, R.D. Metamorphism on Naxos; petrology and geothermal gradients. Am. J. Sci. 1976, 276, 1225-1253. [CrossRef]

81. Siebenaller, L. Fluid Circulations during Collapse of an Accretionary Prism: Example of the Naxos Island Metamorphic Core Complex (Cyclades, Greece). Ph.D. Thesis, University of Lorraine, Lorraine, France, 2008.

82. Henley, R.W.; Ellis, A.J. Geothermal systems ancient and modern: A geochemical review. Earth Sci. Rev. 1983, 19, 1-50. [CrossRef]

83. Fournier, R.O. The behaviour of silica in hydrothermal solutions. Geology and geochemistry of epithermal systems. Rev. Econ. Geol. 1985, 2, 45-61.

84. Hitzman, M.W.; Reynolds, N.A.; Sangster, D.F.; Allen, C.R.; Carman, C.E. Classification, Genesis, and Exploration Guides for Nonsulfide Zinc Deposits. Econ. Geol. 2003, 98, 685-714. [CrossRef]

85. Boni, M.; Large, D. Non sulfide Zinc Mineralization in Europe: An Overview. Econ. Geol. 2003, 98, 715-729. [CrossRef]

(C) 2019 by the authors. Licensee MDPI, Basel, Switzerland. This article is an open access article distributed under the terms and conditions of the Creative Commons Attribution (CC BY) license (http://creativecommons.org/licenses/by/4.0/). 